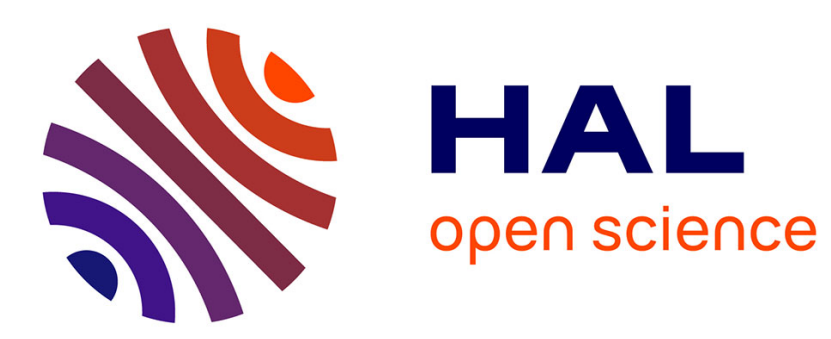

\title{
Fossil oceanic core complexes recognized in the blueschist metaophiolites of Western Alps and Corsica
}

Yves Lagabrielle, Alberto Vitale Brovarone, Benoît Ildefonse

\section{To cite this version:}

Yves Lagabrielle, Alberto Vitale Brovarone, Benoît Ildefonse. Fossil oceanic core complexes recognized in the blueschist metaophiolites of Western Alps and Corsica. Earth-Science Reviews, 2015, 141, pp.126. 10.1016/j.earscirev.2014.11.004 . insu-01096467

\section{HAL Id: insu-01096467 https://hal-insu.archives-ouvertes.fr/insu-01096467}

Submitted on 17 Dec 2014

HAL is a multi-disciplinary open access archive for the deposit and dissemination of scientific research documents, whether they are published or not. The documents may come from teaching and research institutions in France or abroad, or from public or private research centers.
L'archive ouverte pluridisciplinaire HAL, est destinée au dépôt et à la diffusion de documents scientifiques de niveau recherche, publiés ou non, émanant des établissements d'enseignement et de recherche français ou étrangers, des laboratoires publics ou privés. 


\section{Fossil Oceanic Core Complexes recognized in the blueschist metaophiolites of Western Alps and Corsica.}

by

Yves Lagabrielle (1), Alberto Vitale Brovarone (2), Benoît Ildefonse (3)

(1) Observatoire des Sciences de l'Univers de Rennes, Géosciences Rennes - UMR 6118 263 Avenue du General Leclerc CS 74205, 35042 RENNES CEDEX yves.lagabrielle@univ-rennes1.fr

(2) Institut de Minéralogie, de Physique des Matériaux, et de Cosmochimie (IMPMC), Sorbonne Universités - UPMC Univ Paris 06, UMR CNRS 7590, 4 Place Jussieu, F-75005 Paris, France alberto.vitalebrovarone@gmail.com

(3) Géosciences Montpellier, Université Montpellier 2, CNRS UMR 5243, CC60, 34095 Montpellier cedex 05, France (ildefonse@um2.fr)

This work is dedicated to the memory of Bruno Lombardo. As a scientist and as a person, Bruno gave a lot to the study of Alpine ophiolites. Results discussed in this work also benefit from his work and his great passion for geology in general. 


\section{Abstract}

Tethyan ophiolites show an apparent poorly organized association of ultramafic and mafic rocks. By contrast to the complete mantle-crustal sections of Semail-type ophiolite sheets, Tethyan ophiolites are characterized by a smaller amount of mafic rocks (gabbros and basalts), by the absence of any sheeted dyke complex and by the frequent occurrence of oceanic sediments stratigraphically overlying mantlederived peridotites and associated gabbroic intrusions. Therefore, they are considered as typical remnants of oceanic lithosphere formed in slow-spreading environment or in ocean-continent transition at distal passive margins. In the very first models of formation of the Tethyan ophiolites, in the years 1980, the geodynamical processes leading to mantle unroofing were poorly understood due to the paucity of data and concepts available at that time from the present-day oceans. In particular, at that time, little work had focused on the distribution, origin and significance of mafic rocks with respect to the dominant surrounding ultramafics. Here, we reconsider the geology of some typical metaophiolites from the Western Alps and Corsica, and we show how results from the past decade obtained in the current oceans ask for reassessing the significance of the Tethyan ophiolites in general. Revisited examples include a set of representative metaophiolites from the blueschists units of the Western Alps (Queyras region) and from Alpine Corsica (Golo Valley). Field relationships between the ophiolitic basement and the metasedimentary/metavolcanic oceanic cover are described, outlining a typical character of the Tethyan ophiolite lithological associations. Jurassic marbles and polymictic ophiolite metabreccias are unconformably overlying the mantle-gabbo basement, in a way strictly similar to what is observed in the non-metamorphic Appenine ophiolites or Chenaillet massif. This confirms that very early tectonic juxtaposition of ultramafic and mafic rocks occurred in the oceanic domain before subduction. This juxtaposition resulted from tectonic activity that is now assigned to the development of detachment faults and to the formation of Oceanic Core Complexes (OCCs) at the axis of slow spreading ridges. This fundamental Plate Tectonics process is responsible for the exhumation and for the axial denudation of mantle rocks and gabbros at diverging plate boundaries. In addition, field relationships between the discontinuous basaltic formations and the ultramafic-mafic basement indicate that this tectonic stage is followed or not by a volcanic stage. We discuss this issue in the light of available field constraints.

\section{Key words}

Metaophiolites; Western Alps; Corsica; mantle exhumation; slow-spreading ridge; Oceanic Core Complex; detachment fault; gabbro intrusion. 


\section{Introduction}

Metaophiolites exposed in the internal units of the Western Alps and Corsica were subducted during the closure of the Piemont-Ligure ocean, a segment of the Jurassic Tethys located between the Eurasian and the Apulian-African continents (Bernoulli et al., 1979; Beccaluva et al., 1984; Ricou et al., 1985; Pognante et al., 1986; Lemoine and Trümpy, 1987; Weissert and Bernoulli, 1985; Stampfli et al., 1998; Schmid et al., 2004; Handy et al., 2010, and references therein). In contrast with the thick sections of large ophiolite sheets such as the Semail Nappe in Oman, the Western Alps and Corsica metaophiolites are characterized by a relatively small amount of mafic rocks (metagabbros and metabasalts), by the absence of any sheeted dyke complex and by the frequent occurrence of oceanic sediments stratigraphically overlying variably hydrothermalized mantle-derived peridotites and associated gabbroic intrusions. These associations, which do not fit the "Penrose" three-layers model (Anonymous, 1972), also characterize the ophiolites of the Appennine belt as recognized by many geologists since 1960 (e.g., Decandia and Elter, 1969; 1972; Elter, 1972; Cortesogno et al., 1975; Barrett and Spooner, 1977; Abbate et al., 1980; Molli, 1996). During the last 30 years, authors have highlighted the strong affinities between the Tethyan ophiolites of the Alpine blueschist units and the oceanic lithosphere emplaced at present-day slow spreading ridges (Lombardo and Pognante, 1982; Tricart and Lemoine, 1983, 1991; Lagabrielle and Cannat, 1990; Lagabrielle and Lemoine, 1997). In the mean time, similar observation highlighting the processes of mantle and lower crustal sections exhumation were reported from the Northern Apennine ophiolites (Molli 1995; 1996; Tribuzio et al., 1997). Alternatively, based on the occurrence of continent-derived remnants such as micaschists and granitoid clasts in the sedimentary cover of some of these metaophiolites (e.g., Caby et al., 1971; Polino and Lemoine, 1984), an origin from the lithosphere formed at the ocean-continent transition (OCT) of the ancient Tethyan margins has also been proposed. The model of "distal-continental margin" environment for the emplacement of the serpentinized mantle has been applied to the Alps as well as to the Appennine and Corsica (Lemoine et al., 1987; Boillot and Froitzheim, 2001; Marroni, et al., 1998, 2001; Manatschal and Nievergelt, 1997; Froitzheim and Manatschal, 1996; Desmurs et al., 2002; Manatschal and Muntener, 2009; Vitale Brovarone et al., 2011; Meresse et al., 2012; Masini et al., 2013; Beltrando et al., 2014). Therefore, it is now established that the Tethyan ophiolites have been sampled from different regions of the Tethys ocean, including the distal, hyper-extended passive margins and the more internal (ultra-?) slow-spreading center (see review in Lagabrielle, 2009).

As our knowledge of the Alpine ophiolite geology was increasing, fundamental progresses were also being made in our understanding of the formation of the lithosphere at slow- and ultra-slow-spreading ridges. In particular, the concept of oceanic core-complexes (OCC) now explains how mantle rocks and gabbros are exposed on the seafloor by large detachment faults (e.g., Escartin et al., 2003, 2008; Smith et al., 2008; MacLeod et al., 2009; Escartín and Canales, 2011). This provides clues to decipher the significance of some puzzling Tethyan ophiolite associations in regions where the Alpine 
deformation was regarded as the major cause of ophiolite dismembering. In this article, we show how our knowledge of the OCC architecture helps understanding the apparent poorly organized association of metagabbros, serpentinites and metabasalts forming the oceanic basement of blueschist units of the Western Alps and Corsica. A similar comparison has been successfully conducted in the Chenaillet Ophiolite in the Franco-Italian Alps, which represents a well-preserved ocean-floor sequence that was only weakly overprinted by Alpine metamorphism during its emplacement in the Alpine nappe stack (Manatschal et al., 2011). Lithological similarities with slow spreading ridges were also reported from the Northern Apennine ophiolites (Tribuzio et al., 1999; 2000; Principi et al., 2004).

\section{The metaophiolites of the Western Alps blueschists units : a case study in the Queyras region}

\subsection{Regional geology, age of metamorphism}

The Alpine ophiolites form discrete tectonic bodies scattered within the most internal units of the Alpine belt (fig. 1). They were emplaced following the closure, subduction and exhumation of some remnants of the Piemonte-Ligurian ocean. Their metamorphic overprint developed during subduction and collision events at various metamorphic conditions, from low-pressure (prehnite-pumpellyitefacies) and medium-pressure (blueschist-facies) to high-pressure (HP) (eclogite-facies) conditions. The blueschist-facies ophiolite bodies are small-sized and are included within large volumes of oceanic metasediments : the Schistes Lustrés (s.s.). By contrast, the eclogite-facies metaophiolites, such as the Monviso, Lanzo and Zermatt units are more voluminous, and are associated with restricted volumes of metasediments.

The Schistes Lustrés tectono-stratigraphic complex hereafter the Schistes Lustrés complex is composed of a stack of units comprising dominant oceanic metasediments (Schistes Lustrés s.s.) and their metaophiolite basement rocks in various proportions (Deville et al., 1991; Lemoine, 2003). In the Southwestern Alps, the blueschist-facies terranes of the Schistes Lustrés complex are well exposed in the Queyras region (fig. 2). The Queyras units lie structurally above the eclogite-facies Monviso metaophiolites, which in turn overlies the Dora-Maira internal crystalline massif representing the eclogitized distal European margin and including ultra-HP slices. U/Pb ages of coesite-bearing rocks from the Dora-Maira massif (Tilton et al. 1991; Gebauer et al. 1997; Rubatto and Hermann, 2001) suggest that crystallization occurred at $35 \mathrm{Ma}$ under PT conditions of more than $30 \mathrm{kbar}$ and $700^{\circ} \mathrm{C}$ (Chopin, 1984). Fission track data (Gebauer et al., 1997) show that these Ultra-HP rocks attained $250^{\circ} \mathrm{C}$ at ca. $29 \mathrm{Ma}$, implying very rapid cooling and decompression (see also Rubatto and Hermann 2001). The (ultra-) HP metamorphism in the Dora-Maira massif occurred about 10 Ma later than the eclogitic peak in the Monviso units. The age of the eclogitization of the Monviso ophiolite is estimated to be $49 \pm 2$ Ma using the Ar/Ar method (Monié and Philippot, 1989) and the Lu/Hf method (Duchêne 
et al., 1997b), and $62 \pm 9 \mathrm{Ma}$ using the $\mathrm{Sm} / \mathrm{Nd}$ method (Cliff et al., 1998). The contact separating the blueschist Queyras units from the eclogitic Monviso units is a polyphased extensional shear zone interpreted to have accomodated the exhumation and uplift of the deeper and more internal units during the late orogenic stages (Ballèvre et al., 1990). To the west, the Briançonnais units of the intermediate European margin are retrothrusted over the Schistes Lustrés complex.

In the Queyras area, the Schistes Lustrés complex is well exposed along the Guil valley and along the Aigue-Blanche valley, in the surroundings of St Véran (fig. 3). It shows different degrees of Alpine metamorphism, from low-grade blueschist to blueschist-facies conditions, followed by late greenschists-facies overprint (Schwartz et al., 2000, 2006; Agard et al., 2001). Fission track thermochronology on apatites and zircons suggests that the western Queyras possibly cooled below $300{ }^{\circ} \mathrm{C}$ between 39 and $31 \mathrm{Ma}$ (Schwartz et al., 2007). The onset of exhumation of the Schistes Lustrés complex is broadly contemporaneous with the initial continental subduction of the Dora-Maira massif. The cooling evolution of the Queyras Schistes Lustrés and the Mont Viso after $30 \mathrm{Ma}$ is regarded as synchronous with the onset of exhumation of the Dora-Maira massif.

Three superposed units are distinguished in the Schistes Lustrés complex of the Queyras area based on detailed geological mapping and analysis of metamorphic overprint (Lagabrielle, 1987, 1994; Lagabrielle and Polino, 1988; Tricart et al., 2003; Schwartz et al., 2013) (Figs. 3 and 4). The metamorphic overprint decreases upsection, and each unit displays different lithostratigraphic sequences that are summarized as follows, from the bottom to the top.

a. The lower unit consists of $10 \%$ ophiolites and $90 \%$ metatediments. The ophiolites are composed of dominant serpentinites and minor intrusive metagabbros and metabasalts. They form a thin continuous body resting tectonically atop the Mont Viso eclogitic unit (fig. 3 and 4). The metasediments consist of a thick pile of dominant calcschists affected by kilometer-sized to decimeter-sized recumbent folds representing the original cover of the ophiolites (Lagabrielle, 1987, 1994). The calcschists overlie marbles and metaradiolarites, the typical association forming the cover of the Late Jurassic Tethyan metaophiolites (Lemoine et al., 1970). The calcschists contain numerous olistoliths of ophiolitic material, together with layers of ophiolitic metabreccias, phyllitic marbles, metacherts and micaschists. Some of the largest mafic olistoliths, such as the pillow lavas of the Roche Mouloun massif (fig. 3) still exhibit well preserved remnants of their primary oceanic sedimentary cover (Le Mer et al., 1986). A Late Cretaceous age for the calcschists has been proposed by analogy with wellpreserved sedimentary sequences exposed in the Apennines (Lemoine et al., 1970; Lagabrielle 1987 and references therein), and because of the occurrence of possible relicts of planktonic microfaunas (Lemoine et al., 1984; Marthaler et al., 1986; Lagabrielle, 1987). The thickest ophiolitic metabreccias levels have a mafic composition and are associated with gabbroic and ultramafic olistoliths in the 
northern part of the study area, around the Bric Bouchet summit (fig. 3). They are interpreted as debris-flows of basaltic composition (Lagabrielle and Polino, 1985).

b. The intermediate unit shares many characteristics with the basal unit. It displays similar metasedimentary suites including a rich variety of hm-sized ophiolitic olistoliths that are best exposed in the area between Rouchon and Col Agnel (fig. 3). By contrast to the lower unit, the ophiolitic basement of the intermediate unit is not continuous. It consists of a series of boudinaged slices of metabasalts, metagabbros and serpentinites exposed in the following massifs from north to south: the Pelvas d'Abriès metagabbros, the Pic des Lauzes-Peyroun metagabbros and metabasalts, the Crête des Lauzes serpentinites, the Rocca Bianca metagabbros and metabasalts, the Farneireta serpentinites and the Tête des Toillies metabasalts. In the intermediate unit, but outside the study area, near the village of St Véran (fig. 3), relicts of radiolarians have been discovered within folded metacherts lying atop the serpentinites of the Roche Noire massif (de Wever and Caby, 1982). This confirms the MiddleLate Jurassic age assigned to the ophiolitic basement in the southwestern Alps region, on the basis of lithostratigraphic comparisons with the Apennines ophiolites (Lemoine et al., 1970), and additional discovery of fossil radiolarites in blueschist ophiolitic units close to the Rocca Bianca massif, south of the study area (Schaaf et al., 1985; de Wever et al., 1987).

c. The upper unit is the largest unit exposed in the Queyras region. It consists of dominant calcschists and generally lacks ophiolitic material. It tectonically overlies both the lower and intermediate units. Its Late Cretaceous age has been proposed based on the discovery of possible relicts of planktonic foraminifera (Lemoine et al., 1984).

\subsection{Geology of the Pelvas-Taillante ophiolitic complex}

The Pelvas-Taillante ophiolitic complex belongs to the ocean basement of the intermediate unit. It is composed of a few mafic and ultramafic bodies exposed on both sides of the Guil valley, north and south of the La Monta village (fig. 3). To the north, the Pelvas d'Abriès (or Pic du Pelvas, or Monte Palavas) is a pyramidal body, about $1 \mathrm{~km}^{2}$ large, made up of layered, locally pegmatitic gabbro associated with minor serpentinite slices along its western border (figs. 5, 6 and 7) (Lagabrielle et al., 1985). The gabbros are typically high level dominant $\mathrm{Ca}-\mathrm{Mg}$ and minor Fe-Ti gabbros and troctolites. Rare, late doleritic intrusions are observed, indicating late exhumation close to the sea-floor. At the southeastern corner of the Pelvas body, dark layers of ultramafic composition, a few meters thick, are interlayered within the gabbros (fig. 7). They have been first interpreted as cumulate-like units (Bearth et al., 1975). More recently they were regarded as ultramafic intrusions escaped from the base of a magma chamber within higher-level gabbros (Ambrics and Bertrand, 1999). The marks of both oceanic and Alpine metamorphism are frequent. A foliation defined by a layering of flaser-gabbros 
levels is well developed in the NE corner. Flaser-gabbros are crosscut by undeformed veins of more evolved magmatic material indicating that this foliation is of oceanic origin (Ambrics and Bertrand, 1999).

To the south, the Peyroun-Taillante ophiolitic complex is composed of an assemblage of various mafic and ultramafic slices, as follows, from north to south (figs. 8 and 9).

(1) The magmatic breccias of the Peyroun body consist of brecciated metadolerites intruded by two generations of more differenciated, light coloured magmatic rocks. The texture is typical of hydraulic fracturation. These rocks have been interpreted as an assemblage of mafic dikes from the top of a small magma chamber hosted by mantle rocks and later cross-cut by differenciated magmas (Pinet et al. 1989). The leucocratic rocks were dated at 196 +/- 13.9 Ma (Carpena and Caby, 1984), but this age is highly questionable.

(2) The Pic des Lauzes body is composed of basal layered metagabbros underlying a metavolcanic sequence made up of alternating pillow-lavas, pillow metabreccias and pelagic metasediments (marbles and schists). Based on a detailed field analysis of the relationships between the metabasalts and the metagabbros, Pinet et al. (1989) concluded that the volcanic sequence was emplaced directly on the gabbros as they were exposed on the seafloor. Metabasaltic dikes cross-cutting the metagabbros can be observed in the numerous voluminous blocks, that compose the paleo-rock fall of "La Roche Ecroulée" (see location in figs. 8, 9 and 10). These spectacular outcrops (fig. 11) show that the gabbros were already at a shallow level when they were cross-cut by the basalts.

(3) The Crête des Lauzes body is composed of fully serpentinized peridotites. The ultramafic rocks lie in tectonic contact over the metabasalts of the Pic des Lauzes body (fig. 9). A thin tectonic slice of metagabbros is observed within this tectonic contact (fig. 8). The ultramafic body progressively thins southwards where it forms the basement of the Taillante pelagic metasediments. The tip of the ultramafic body corresponds to the hinge of a km-wide recumbent fold. Similar folds are numerous, though less visible, in the study area, as represented in cross-sections of figure 4.

The Pelvas metagabbros have been early considered as cumulate gabbros emplaced in a small magma chamber (Bearth et al. 1975). In their reconstruction of the paleo-oceanic basement, Pinet et al. (1989) consider that they formed the core of a km-wide magma chamber, intrusive into the surrounding mantle rocks, and that they were possibly connected to the gabbros of the basal part of the Pic des Lauzes before the Alpine tectonics. The magmatic breccias of the Peyroun are regarded as the upper part of this magma pocket composed of mafic products crosscut by doleritic and differenciated dikes.

\subsection{Lithostratigraphy of key-sections along the Pelvas-Taillante complex (figs. 12 to 14)}


The metasedimentary sections associated with the metagabbros of the Pelvas body are well exposed at the base of the western flank of the massif, and on its northeastern corner. Along the crest immediately south of the Col d'Urine, the sequence is overturned, and light-colored, silicic marbles assignable to the Late Jurassic form a $10 \mathrm{~m}$ high cliff beneath the metagabbros. The contact between the marbles and the metagabbros is primary as evidenced by the occurrence of small metagabbros debris in the marbles close to the metagabbros (fig. 13; Lagabrielle et al., 1984, Ballèvre and Lagabrielle, 1994). The tectonic foliation of the metagabbros, parallel to the magmatic bedding is oblique to this contact, indicating a pre-Alpine origin for this deformation (fig. 13). The marbles are underlain by a succession of detrital layers of various lithologies including serpentinized metabreccias with gabbroic clasts and reworked ophicalcite debris. Thin levels of marbles can be observed within the metabreccia succession. Along the western border of the Pelvas massif, in the Sagnes Clauses and Peyra Plata areas, the gabbros are separated from the metasediments by a few meter-thick layer of serpentineschists. The ultramafic rocks are overlain by ultramafic or gabbro-rich metabreccias and by alternating marbles and calcschists. Serpentine metabreccias including gabbro olistoliths associated with basaltic metabreccias (now prasinites) are observed over the marbles and calcschists. Primary sedimentary contact between ultramafic breccias and Jurassic marbles are well exposed along these sections (fig. $13)$.

The metasedimentary sections associated with the Peyroun-Taillante bodies are considerably thicker than the sections exposed around the Pelvas massif. The most complete sequence is exposed west of the Crête des Lauzes along the suspended valley of the Lakes Foréant and Egourgéou (figs. 8 and 9). It has been deposited over the serpentinized peridotites of the Crête des Lauzes. The basal levels of the sequence consist of talc-schists and chloritites passing progressively to serpentinite metabreccias and ophicalcites (fig. 14). These ultramafic-rich layers are overlain by marble layers and rare calcschists, which in turn are capped by a 20-30 m thick formation of metabasalts alternating with thin layers of pelagic metasediments. The metabasalts underlie a thick sequence of metasediments that form the entire cliff of the Crête de la Taillante. This sequence includes calcschists at the base, and alternating layers of marble, quartzite, and basaltic metabreccias (now prasinites) in its upper part. These metasediments form km-scale recumbent folds well observed in the Crête de la Taillante cliff (fig. 9).

\subsection{Geological observations in the Farneireta-Rocca Bianca ophiolitic complex (figs 15, 16)}

The Farneireta-Rocca Bianca complex belongs to a group of ophiolitic bodies lying in the highest regions of the Aigue Blanche and Ubaye valleys (Tricart and Lemoine, 1983; Tricart et al., 1985) (fig. 15). East of the village of St Véran, this group constitutes a rich assemblage of various lithologies belonging to the oceanic paleobasement, and includes serpentinized peridotites, ophicalcites, metagabbros and metaferro-gabbros, pillowed metabasalts and pillow-metabreccias. Siliceous lightgrey marbles associated with metaradiolarites are found in contact with the metaophiolitic bodies. This 
association is typical of the Jurassic cover of the Liguro-Piemont ophiolites and outlines the presentday limit of the top-surface of the oceanic basement. The lateral continuity of the Jurassic marble layer is a key-feature in these ductily deformed regions. It allows to follow the paleo-oceanic basement floor all along the $\mathrm{km}$-scale folded structures. Locally, ophiolitic sedimentary metabreccias of various lithologies are found between the marbles and the ophiolitic basement. They are composed of serpentinites, gabbros, and basalt debris mixed in different proportions, and are preserved in restricted paleo-depressions. This suggests deposition of clastic products of various lithology in relation with active oceanic faults. They directly reflect the lithological heterogeneity of the paleobasement, and indicate that the seafloor was tectonically active (Tricart and Lemoine, 1983; Lagabrielle and Cannat, 1990).

The geometry of the metaophiolitic bodies forming the Farneireta - Tête des Toillies - Rocca Bianca complex can be easily reconstructed based on the geological mapping of the ophiolite-sediment boundary at a km-scale. As shown on the synthetic cross-sections in figure 15, the structure of the ophiolitic basement is characterized by the association of ductile shearing, recumbent folding and boudinage. This deformation occurred under relatively high temperature in the early stages of the Alpine compression. The Farneireta pyramidal mountain is composed of folded serpentinites and their marble cover, passing lateraly to meta-pillowlavas, forming the Tête des Toillies summit (fig. 15). To the northeast, the marble layer thins considerably but can be followed along a few kilometers towards the Rocca Bianca mafic complex. The Rocca Bianca complex forms the head of a major recumbent fold and comprises a core of metagabbros embedded within basaltic metabreccias and bigenic basaltgabbro metabreccias. At the base of the cliff forming the italian side of the Rocca Bianca summit, the marbles are in contact with the metagabbros with a reverse polarity. On the western flank of the Rocca Bianca massif, along the valley hosting the upper and lower Lacs Blanchet, the Jurassic marbles are well exposed and their polarity is normal. The primary contact of the marbles with the metapillowlavas and the basaltic meta-breccias can be observed here over very large surfaces (fig. 16). Field evidence is clear in this area that the sedimentary cover of the ophiolites is lying over a rich assemblage of various lithologies including massive metagabbros and metabasalts associated with polymictic ophiolitic metabreccias.

\section{Ophiolitic bodies from blueschist units in Corsica : a case study in the Golo valley}

\subsection{Regional background}

Alpine Corsica occupies the northeastern part of the island, and consists of a stack of tectonic units originally belonging to the Corsica continental margin or to the Alpine Tethys basin, and displaying 
different Alpine metamorphic overprints (see review by Vitale Brovarone et al., 2013 and references therein) (fig. 1). Three main domains can be distinguished.

(1) The Corsica continental margin units experienced little to low-grade blueschist-facies Alpine metamorphism.

(2) The Schistes Lustrés complex represents an equivalent of the Piemonte units of the Western Alps. These terranes comprise both ocean-continent transitional terranes (Vitale Brovarone et al., 2011; Meresse et al., 2012) and more internal remnants of the Tethys Basin that experienced variable Alpine metamorphic overprint, from blueschist- to eclogite-facies conditions (Ravna et al., 2011; Vitale Brovarone et al 2013, 2014 and references therein)

(3) The so-called Nappes Supérieures include both continental and ophiolitic rocks that experienced little or no Alpine metamorphism.

Several studies have focused on the overall architecture, chemical composition, and age of the remnants of the Tethys Ocean preserved in this orogenic belt, especially in the poorly metamorphosed Nappes Supérieures (e.g., Beccaluva et al., 1977; Ohnenstetter, 1981; Ohnenstetter et al., 1981, Caron, 1977; Saccani et al., 2008; Piccardo and Guarnieri, 2010; Rampone et al., 2009; Sanfilippo and Tribuzio, 2013a, Vitale Brovarone et al., 2013). Based on structural, petrological and geochemical data, Sanfilippo and Tribuzio (2013a), reconsidered the nature of the Pineto ophiolitic sequence in Corsica in the light of the most recent knowledge of present-day slow-spreading mid-ocean ridges. In the more deeply metamorphosed units of the Schistes Lustrés complex, the slow-spreading concept has long been applied (e.g. Lagabrielle and Cannat, 1990; Lagabrielle and Lemoine and 1997; see also section 2 above). However, if recent attention has been paid to ocean-continent transitional terranes preserved in the HP terranes of Corsica (Vitale Brovarone et al., 2011; Meresse et al., 2012), up to now only little observations exist from oceanic sections lacking widespread continent-derived material. Here we focus on the metaophiolites included in the blueschist units of the Schistes Lustrés complex in the Golo valley, a classic type locality for the Corsican metaophiolites with very little continental affinity (e.g., Durand-Delga, 1978).

\subsubsection{Blueschist-facies metaophiolites in the Golo valley (fig. 17)}

In the area between the Bigorno pass and the village of Saliceto, left and right banks of the Golo valley, respectively, large bodies of blueschist facies metaophiolites crop out together with their metasedimentary cover sequences (Vitale Brovarone et al., 2014) (fig. 17A). We herein focus on two main sectors, the Bigorno pass, and an elongated metaophiolite body located in the proximity of the village of Morosaglia. 
In the Bigorno pass area a thick ultramafic body forms the top of the Righia Buia massif. It mainly consists of fully serpentinized peridotites locally affected by intense deformation and leading, in some areas, to the formation of typical serpentinite-schists. The top of these serpentinites crops out in several localities along the southeastern flank of the Righia Buia massif, and is marked by refolded discontinuous lenses of carbonated rocks alternatively referred to as meta-ophicarbonates (Levi et al., 2007) or carbonated peridotites (Vitale Brovarone et al., 2014) (fig. 17B, C). These rocks are followed upsection by a metasedimentary sequence including metapelites alternating with marbles, and frequent layers of ophiolitic metabreccias mostly consisting of gabbro or microgabbro clasts and carbonated peridotites (fig. 17D). These metabreccias crop out extensively in this area (see "Trondhjemite unit" in Rossi et al., 2002). In the same are, large bodies of metagabbro include both $\mathrm{Mg}$-Al-rich and Fe-Ti metagabbros. Their structural relationships with the serpentinites, i.e. within or atop, however, are not directly observed in the field.

In the Morosaglia area, a large sliver of serpentinites forms an elongated body running NS for ca. 4 $\mathrm{km}$. These rocks are texturally comparable with the Righia Buia serpentinite massif, and include massive, poorly deformed serpentinized peridotites and more intensely deformed serpentinite schists. In the northern tip of this body, serpentinites are associated with a large metagabbro body that extensively crops out in the Monte Campo Rotondo massif. Within this massif, highly strained metagabbros preserve relicts of HT amphiboles such as kaersutite and magnesioastingsite (unpublished microprobe data from Vitale Brovarone et al. ) (Fig. 17E), and testify for subsolidus hydrous deformation in the oceanic environment. Local basaltic dykes cut across the metagabbro (fig. 17E). Pillow metabasalts are found only in very local and small bodies, such as in the Rocca Soprana village. The aforementioned mafic and ultramafic rocks are overlain by a thick (2-4 m) sliver of metacherts, followed upward by metapelites and interlayered marbles equivalent to the Replatte Formation in the Western Alps, the metamorphic equivalent of the Early Cretaceous Palombini shales of the Apennines (Lemoine et al., 1970). A thick mafic complex also occurs at the southern tip of the serpentinite sliver, but with significantly different lithostratigraphic features. Metavolcanics are the dominant lithology and forms a ca. $200 \mathrm{~m}$ thick sequence characterized by well-preserved pillow basalts that is best exposed in the proximity of the Saliceto village (see "Saliceto massif" in Sedan, 1983) (fig. 17F). Metagabbros are scarce compared to the Monte Campo Rotondo body. In this area, the basement-cover contacts are poorly exposed but field observations suggest that primary relationships have not been strongly reworked by the Alpine tectonics.

\section{Discussion : reconstructing fossil OCCs in the Alpine-Corsica blueschist units.}

4.1. Geological significance of the metasedimentary sections associated with the Alpine ophiolites : a summary. 
The metasediments closely associated with the metaophiolitic bodies in the Queyras region and Corsica have long been regarded as fundamental witnessess of the geological evolution of the oceanic basement during the opening of the Tethyan oceanic realm (e.g., Lemoine and Tricart, 1986; Lagabrielle and Cannat, 1990). The stratigraphic sections in direct contact with the metaophiolites contain a wide variety of mafic and ultramafic metabreccias associated with pelagic metasediments, which are the record of the numerous events occurring at the seafloor. These events include: (1) tectonic denudation of the ultramafic basement including intrusions of gabbros, (2) subsequent normal faulting at shallow level and erosion of the corresponding fault scarps, (3) extrusion of basaltic magmas on an heterogeneous seafloor of ultramafic-mafic composition. The variable superposition of these processes and the subsequent orogenic reworking may result in puzzling lithological associations typical of all Alpine ophiolites, as emphasized by numerous authors since more than 50 years (see compilation by Lagabrielle, 2009). In the following, we show how observations from present-day oceanic ridges provide a consistent link among these characters.

Comparisons of Alpine metaophiolitic sections with the geology of present-day slow-spreading ridges have been made in the years 1980. During this period of intensive submarine explorations, many cruises conducted along the MAR and the SWIR provided important informations relative to the frequent occurrence of ultramafic seafloors in the present-day oceans (see review in Lagabrielle and Cannat, 1990 and Lagabrielle, 2009). However, at that time, the reconstructions of the architecture of the oceanic lithosphere obtained in the oceans as well as in the mountain belts were rough. For this reason, no viable mechanical processes were proposed that accounted for the presence of mantle and gabbroic rocks at the axis of slow-spreading ridges. The first model of mantle exhumation along a single, major shallow dipping shear zone, an oceanic detachment fault, has been proposed by Karson in 1987 (Karson, 1990) for the MARK area, south of the Kane Fracture Zone at the Mid-Atlantic Ridge (MAR). It must noticed that Van Andel and Bowin (1968), proposed 20 years earlier a model, outlining the role of brittle deformation and large scale shallow dipping normal faults for explaining the ridge flank morphology and the presence of peridotites on the seafloor at the MAR at $22^{\circ} 30^{\prime} \mathrm{N}$. The concept of detachment faulting was rapidly applied to the Tethyan ultramafic basement by Lemoine et al., (1987). This concept helped better understanding the way the ultramafic and gabbroic rocks are extracted at a large scale from the deep oceanic basement to form the seafloor. However, it does not provide explanations for the detailed geological evolution of the ophiolitic bodies at a kilometer scale.

In the following, we show how the detailed knowledge of the architecture and evolution of OCCs is able to largely improve our understanding of the significance of the Alpine ophiolites. Such a link between marine constraints and field observations was applied successfully to the Chenaillet massif. In this weakly deformed ophiolite, pillow lavas showing a MORB signature overlie gabbros and serpentinized mantle rocks. The relationships between the volcanic rocks and the mafic/ultramafic 
basement were not clearly established. Based on new field observations at the top surface of the gabbros and serpentinites, Manatschal et al. (2011) proposed that an oceanic detachment fault exhumed the gabbros and mantle rocks at the seafloor in a way similar to OCCs described in presentday oceans. Here we examine how a similar comparison can be attempted also to the Alpine blueschists units.

\subsection{Architecture of present-day OCC}

Oceanic core complexes are axial structures of slow- and ultra-slow spreading ridges in which lowercrust and upper-mantle rocks are exposed at the seafloor. They form through slip on detachment faults rooted below the spreading axis, typically over 1 to 3 million years. The first detected oceanic core complexes were identified in the Atlantic Ocean (e.g., Atlantis Massif, Kane OCC, Dante's dome; Cann et al., 1997; Tucholke et al., 1998, 2001). Since then, numerous similar structures have been identified, particularly along the Mid-Atlantic Ridge (e.g., Reston et al., 2002; Smith et al., 2006, 2008; Escartin et al., 2003, 2008; Dick et al., 2008; MacLeod et al., 2002, 2009), the Southwest Indian Ridge (e.g., Searle et al., 2003; Cannat et al., 2006; Sauter et al., 2013; Zhao et al., 2013), and in backarc basins (Ohara et al., 2001, 2003). Some of these structures have been sampled by drilling (Dick et al., 2000; Ildefonse et al., 2007a, 2007b, and references therein; Blackman et al., 2011), showing that the footwall can be composed of dominant mafic plutonic and minor ultramafic rocks, capped by a major shear zone that includes hydrous phyllosicates, notably ubiquitous talc-chlorite schists which facilitate slip at low fault dips (e.g., MacLeod et al., 2002; Escartin et al., 2003; Schroeder and John, 2004; Boschi et al., 2006; Karson et al., 2006; Picazo et al., 2012). Microstructural observations, mineral chemistry, and the spatial distribution of deformation fabrics recorded in outcrop samples collected from OCC suggest that strain is localized near the subhorizontal domal surface. This supports the hypothesis that OCCs represent the exposed footwall of detachment faults. Strain is localized onto the fault by reaction-softening and fluid-assisted fracturing during greenschist- and subgreenschist-grade hydrothermal alteration of olivine, clinopyroxene, serpentine, and hornblende to tremolite, chlorite, and/or talc (Schroeder and John, 2004; Boschi et al., 2006; Picazo et al., 2012). In some less common cases, geological observations suggest that the core may be dominantly ultramafic in composition such as at the Cain Dome at the Kane OCC (Dick et al., 2008). Hence, two different end members of OCC have been described : peridotite-hosted and gabbro-hosted OCCs. Such a variability in OCC architecture has to be kept in mind when studying the blueschist ophiolites of the Alpine belt, as shown below.

4.3. Reconstruction of Tethyan OCCs based on the Queyras and Corsican metaophiolites lithostratigraphy

The main input of the OCC model is that it explains the original association between sheared mafic and ultramafic rocks. It also provides an explanation for the very large volume of ophiolitic debris 
reworked in the slow-spreading ridge environments. The presence of a very large volume of sheared and crushed rocks continuously exhumed during the activity of OCC is the major explanation for the constant occurrence of thick clastic ultramafic-mafic sedimentary rocks capping the Alpine ophiolites. Thus, the lithology of the ophiolitic metabreccias is a reliable indicator of the tectonic activity of the seafloor.

The top of OCC domes is a thin layer of sheared serpentinites and talc-chlorite-schists, commonly capping sheared gabbros (flaser gabbros). This suggests that primary talc-chlorite-serpentinite associations found in shear zones between mantle rocks and gabbros or diabase in ophiolites might have formed well before subduction in the oceanic environment during lithosphere spreading. Thus, despite possible reactivation during the Alpine orogenesis, these shear zones experienced a Tethyan tectonic stage. We are aware that this interpretation can hardly be proven in such strongly deformed metaophiolites from blueschists and eclogite units. Further studies would help differentiate shear fabrics and mineralogical assemblages from such contrasting extensional (oceanic) and compressional (Alpine) environments.

Based on the high variety of lithological successions observed in the sedimentary cover of the PelvasTaillante (Queyras) and Golo (Corsica) complex, one may reconstruct the overall architecture of a model of Tethyan OCC. Figure 18 shows the field location of the tectono-stratigraphic sections described in Section 3, and their possible position in a model of slow-spreading ridge axis characterized by mantle exhumation. This model includes an OCC that formed on one side of the ridge axis. Mantle exhumation was followed by the emplacement of pillowed basalts forming the neovolcanic zone. The reference model is taken from the example of the well-known eastern intersection of the MAR with the Kane fracture zone (MARK area) (Juteau et al., 1990a, 1990b; Mével et al., 1991; Cannat et al., 1995a; Karson et al., 1997a, 1997b). In this region the rift valley has an asymetrical cross-section profile with a shallower and steeper western wall as shown in figure 19. Serpentinized upper mantle peridotites and associated mafic plutonic rocks are commonly exposed on the steepest and shallowest part of the axial valley wall. Sheared gabbros and minor serpentinites are exposed along the northeast curved flank of the ridge-transform intersection massif. The gabbros are commonly highly deformed and they are cut by relatively early low angle normal faults and shear zone and more recent vertical normal faults. South of the ridge-transform intersection Massif, the gabbros form a $15 \mathrm{~km}$ long belt. South of this belt there is a $20 \mathrm{~km}$ long serpentine belt. These belts represent the footwall of a major detachment fault marking the edge of an OCC. The axial valley has a continuous neovolcanic ridge where recent volcanic constructions and intense hydrothermal activity are focused. The ridge extends more than $40 \mathrm{~km}$ south of the Kane ridge-transform intersection. It is clear from this location that the basalts have been erupted after the exhumation of the deepest rocks. Hence, the basal contact of the volcanic rocks represents a major temporal and geodynamical discontinuity. 
The main geological informations provided by the tectono-stratigraphic sections ( 1 to 5$)$ located on figure 18 can be summarized as follows:

1. Pelagic sediments and ultramafic-gabbro breccias are lying over a large body of sheared gabbros capped by a thin layer of sheared serpentines which may represent an exposed detachment surface (Sagne Clause section).

2. Pelagic sediments are lying directly over denudated sheared gabbros. Ultramafic-gabbro breccias or large gabbro olistoliths occur at various levels in the sedimentary cover (Monte Campo Rotondo section, Col d'Urine sections).

3. Pelagic sediments and ultramafic breccias are overlying directly exhumed serpentinized peridotites (Taillante, Bigorno sections). Such sections are characterized by the lack of magmatic product overlying the mantle rocks. Locally (Crête des Lauzes section), the serpentinized mantle is capped by sheared talc-schists and chloritites representing an exposed detachment surface. They are in turn covered by ultramafic sedimentary breccias and pelagic sediments.

4. Basaltic pillow lavas and pillow breccia overlie serpentinized mantle (Crête des Lauzes section).

5. Basaltic pillow lavas and pillow breccia overlie exhumed, layered gabbros (Pic des Lauzes, Saliceto sections).

Following a similar approach, we may reconstruct the architecture of another type of OCC, from the lithostratigraphy of the Farneirata-Rocca Bianca and Tête des Toillies ophiolitic bodies. A possible reconstruction, based on the geological sections of Figure 15, is shown in Figure 20. Taking into account the primary association of serpentinites and marbles as observed in the Farneireta massif this reconstruction shows that a large portion of the seafloor was made up of exhumed mantle rocks. This association is also found in nearby ophiolitic bodies such as in the Roche Noire and Cascavelier massifs (Tricart and Lemoine, 1983, 1986), as recalled in the synthetic cartoons of figure 21. Similar situations are extremely frequent and well exposed in other Alpine and Appennine ophiolites (see review in Lagabrielle, 2009). Thus one may wonder whether such large portion of ultramafic seafloor may represent OCC having a non-magmatic core as locally described along the MAR. In the reconstruction of figure 20, we propose that two types of OCC might be sampled by the alpine tectonics. These two types correspond to the peridotite-hosted and gabbro-hosted OCCs as described along the MAR axis.

\subsection{Diversity of gabbroic rocks}

The gabbroic rocks of the Alpine ophiolites include a wide variety of petrographic facies such as layered suites with a strong grain-size heterogeneity, Fe-Ti-rich gabbros and strongly serpentinized olivine-rich troctolites and dunites. Above all, they have been described as relatively small sized bodies, intrusive into the mantle rocks, or as meter-thick sills. The best examples have first been described in the Apennines (e.g., Gianelli, 1977; Gianelli and Principi, 1977; Piccardo, 1977; 
Cortesogno et al., 1978; Abbate et al., 1980). This characteristic has been used as a major evidence to highlight the magma-poor character of the Tethyan paleo-basement (e.g., Caby, 1995). This reasoning was applied to the HP Alpine units by Lombardo and Pognante (1982), and by Lagabrielle and Cannat, (1990).

These main characteristics are remarkably similar to those of the igneous sequences described in the core of present-day OCCs (e.g., Cannat et al., 1995b; Dick et al., 2000; Kelemen et al., 2007; John et al., 2009; Blackman et al., 2011), which are made of numerous, relatively small intrusive units. Dating in the $1.4 \mathrm{~km}$ long section recovered in the core of the Atlantis Massif (IODP hole U1309D) points to a protracted construction of the igneous sequence over a period of 100-200 ka (Grimes et al., 2008). Grain sizes, textures, and lithologies are as variable in drill cores from OCCs as they are in ophiolites. The recovered lithologies in the two deepest OCC holes (ODP Hole 735B and IODP Hole U1309D) range from very primitive olivine-rich troctolites to evolved oxide-rich gabbros and felsic material, and commonly include orthopyroxene-bearing primitive gabbros and gabbronorites (Dick et al., 2000; Ildefonse et al., 2007a; Godard et al., 2009; Blackman et al., 2011). Olivine-rich troctolites from Hole U1309D are particularly interesting; they are cumulate-like ultramafic rocks that contain more than $70 \%$ olivine embedded in poikilitic clinopyroxene and plagioclase, similar to those described in the Pelvas d'Abriès massif (Ambrics and Bertrand, 1999). They occur as relatively thin (maximum 12 meters thick) units at various depths in the hole. Bulk rock geochemical signatures of these troctolites are more primitive than other mafic samples from the ocean crust, and geochemical and microstructural evidence demonstrate that they are not simple cumulate, and that their formation involves a mantle origin and substantial melt-rock interactions (Suhr et al., 2008; Drouin et al., 2009, 2010)

Petrology and geological constraints collectively point to similarities between the Queyras gabbro bodies and the gabbros emplaced at slow-spreading ridges axes and exhumed along OCC detachment. Similar conclusions were reached by authors studying gabbros from other ophiolites belonging to the ancient Ligure-Piémont oceanic basement. Our comparison with oceanic gabbros is in perfect agreement with what has been proposed so far from other Alpine outcrops. In Corsica, comparisons between olivine-rich troctolites and gabbroic successions of the Atlantic massif have been made in the poorly metamorphosed Pineto ophiolite by Sanfilippo and Tribuzio (2013a, 2013b), and similar conclusions are proposed by Vitale Brovarone et al. (under review) in more deeply metamorphosed units. Menna et al. (2007) describe gabbroic rocks from the non-metamophic ophiolite of Liguria having affinities with Atlantic OCC. In this region, the gabbros from Scogna and Rocchetta Vara also include ol-rich troctolites. They belong to a non-volcanic ophiolitic suite, similar to that of the Pelvas body, and have been compared to plutonic rocks emplaced at slow-spreading settings (Renna and Tribuzio, 2011; Sanfilippo and Tribuzio, 2011, 2013b). The complexity of plutonic bodies related to 
OCC tectono-magmatic evolution, however, still requires work, and an integration of data from active oceanic settings and ophiolitic suites exposed onland is needed.

\subsection{Chronology of volcanic activity and faulting}

The most simplistic model accounting for the geological observations reported in this article is presented in figure 22. It shows a 3-steps scenario describing the evolution of an OCC with a tectonic stage followed by a magmatic stage. We are well aware that such a model cannot describe the complexity of the interactions between magmatic and tectonic processes at slow-spreading ridges. Indeed, the chronological relations between igneous and volcanic activity in OCC are complex and depend upon the evolution of single vs. multiple conjugated OCC systems at a given locality. Therefore this model can be used only to report a possible succession of events, but not for describing the entire evolution at the paleo-spreading center during a large span of time.

Regions dominated by the emplacement of OCCs have diverse evolutionary history leading to complex relationships patterns between mantle and volcanic rocks. At modern OCCs, volcanic activity commonly predates the initiation of faulting as shown by the occurrence of basalt-rich hanging wall or basaltic rider blocks (e.g., deMartin et al., 2007; Karson et al., 2006; Reston and Ranero, 2011). Volcanism can also be contemporaneous to, or postdate active detachment faulting, as shown by basalt or dolerite dikes commonly cross-cutting faulted rocks in the detachment fault itself or in the footwall (e.g., MacLeod et al., 2002; Escartin et al., 2003; McCaig and Harris, 2012). Numerical modeling suggests that a certain amount of magmatic product at depth is necessary to initiate the development of large detachment faults at the axis of sow-spreading ridges (e.g., Tucholke et al., 2006; Olive et al., 2010). The last stages in the evolution of an OCC may or may not be characterized by a volcanic stage (neovolcanic zone in Tucholke and Lin, 1994 or MacLeod et al., 2009). The smooth seafloor described by Cannat et al., (2006) corresponds to the amagmatic end-member of slow-spreading ridges systems. This type of seafloor may also succeed to OCC, the final stage of the OCC evolution corresponding then to a reduced magmatic activity. Hence, slow-spreading systems appear to be characterized by complex interactions between faulting and magmatism. In addition, magmatism at depth is not necessarily accompanied by volcanism at the seafloor (e.g., Godard et al., 2009). Finally, although the chronological relations between plutonic and volcanic rocks in OCCs can be locally established, the interpretation of their genetic relations in the now inactive settings is possibly biased by the superposition of diverse and often independent events.

Field observations in metaophiolite complexes locally permit the chronological relations between mantle, gabbroic and volcanic rocks to be defined. However, due to local strong Alpine deformation imprint, the chronological constraints provided by such paleo-OCCs are generally poor. The 
occurrence (e.g., Crête des Lauzes, Tête des Toillies, Saliceto sections) or non-occurrence (e.g. Pelvas d'Abriès and Bigorno sections) of metabasalt in the studied metaophiolite complexes matches the natural complexity and diversity of modern OCCs. In the volcanic-rich bodies of the blueschist-facies metaophiolites, juxtaposition of pillow basalts onto gabbros clearly indicates volcanic activity postdating the exhumation of gabbros at the seafloor. Moreover, basaltic dikes cross-cutting gabbros are relatively common (e.g. Pic de Lauzes, Monte Campo Rotondo). In some cases, undeformed basaltic dykes cut across sheared gabbros, clearly pointing to detachment faulting and gabbro exhumation before volcanic eruption. This is well established in the more external Chenaillet unit of the Southwestern Alps (Manatschal et al., 2011) and is also observed in the sections exposed at the base of the Crête des Lauzes (La Roche Ecroulée) (fig. 11, C, D). The impact of a primary oceanic syntectonic metamorphism affecting gabbroic rocks prior to lava emplacement is also reported from the Apennines ophiolites (Cortesogno et al., 19756; 1996; Sanfilipo and Tribuzio, 2011). Macleod et al., (2002); Escartin et al., (2003); Blackman et al., (2006); John et al., (2009); McCaig and Harris, (2012) provide equivalent observations in modern OCCs. These features collectively indicate volcanic activity that follows the exhumation of gabbroic rocks at sub-seafloor conditions. However, this volcanic activity must be volumetrically limited, as the corrugated detachment faults surfaces that cap OCC's lack volcanic cover. These surfaces commonly carry rafted blocks (e.g., Karson et al., 2006; Reston and Ranero, 2011), which are remnants of basaltic hanging wall. Such remnants of the predetachment faulting volcanics are possibly represented by the basalt-dominated metabreccias that are locally found in the studied metaophiolite complexes (e.g. Rocca Bianca, Bigorno areas). This would indicate the activity of a detachment fault cutting through volcanic crust, as presently inferred in the TAG area for example (deMartin et al., 2007). Finally, owing to the limited exposure and tectonic reworking of metaophiolites compared to active settings, the uncertainty on the chronological and genetic relations between gabbroic and basaltic rocks still remains, and more work in these exhumed complexes is required.

In Figure 20, we have represented pre-and post-OCC volcanic formations in order to account for the possible occurrence of basaltic eruptions before and after the activity of the detachment faults leading to OCC formation. A similar question has been addressed in a different setting involving paleo-margin units of the Platta nappe in the eastern Swiss Alps (Desmurs et al. (2001). Field observations in the Platta Nappe led authors to discuss the synchronocity of basalts eruption and the activity of detachment faults leading to the exhumation of an ultramafic basement. Further field and geochronological studies are therefore encouraged. In particular investigations could focus on the possible occurrence of syn-oceanic shear zones at the base of possible basaltic rafted blocks. In the main reconstruction of figure 20 , we have represented detachment faults having similar dips. There are no constraints on the initial relative orientation of the faults, and a model involving conjugate detachment faults is also possible as shown in lower cartoon of fig. 20. Asymetrical or symetrical 
geometries of low-angle faults at slow-spreading centers has been matter of debate for a long time (see synthesis in Lagabrielle et al., 1998). Recently, alternating activity of detachment faults with opposite dips has been evidenced at the ultra slow-spreading South West Indian Ridge (Sauter et al., 2013). Such geometries are likely to be linked to very low magma budgets leading to the formation of a "smooth seafloor" (Cannat et al., 2006). As a consequence, geometries inherited from various types of fault distribution and attitudes, with conjugate or parallel dips, can be expected in metaophiolites, possibly depending on the paleo-magma budget.

\section{Conclusions.}

In the first models of formation of the Alpine ophiolites, in the years 1970-1990, only two specific characters were outlined: (1) the early exposure of mantle rocks on the seafloor and (2) an overall poor magma budget and a reduced or absent volcanic layer. At that time the mechanism of mantle exhumation at slow-spreading ridges was unknown due to very limited data and concepts available from the present-day oceans. Results from the past two decades obtained along slow-spreading ridges allow the significance of the Tethyan ophiolites to be reassessed.

We confirm here that very early tectonic juxtaposition of ultramafic and mafic rocks in the oceanic domain before Alpine orogeny is responsible for the typical characters observed in the Tethyan ophiolite associations. This juxtaposition occurred during tectonic/magmatic processes that are now assigned to the formation of OCCs at the axis of slow and ultra-slow spreading ridges, responsible for the exhumation and the axial denudation of mantle rocks and gabbros.

Finally, from this careful reappraisal of some fundamental field associations of the Queyras and Corsican HP ophiolitic units, we may point to the following results.

1. The apparent heterogeneity and dismembering of the blueschist ophiolite of the internal domains of the Alpine belt is not enrirely the result of the strong shearing processes that affected the oceanic basement during subduction and further exhumation. Instead, a remarkable heterogeneity of the pristine seafloor dominantly results from the tectonic evolution linked to magmatic and structural events occurring at the diverging plate boudary, well before the initiation of convergence. The development of OCCs in the axial region of slow-spreading ridges leads to the unroofing of gabbroic plutons surrounded by a rim of strongly sheared serpentinites and talc, chlorite-rich schists together with large volumes of ultramafic screes. The OCC model provides a now reasonably well documented framework to explain what was only described as a final result by many authors : the denudation of the mantle rocks and gabbros. In addition, the OCC model implies that numerous serpentinite- 
talc-chlorite shear zones separating various mafic and ultramafic ophiolitic bodies may not systematicaly represent Alpine tectonic contacts.

2. The pristine character of the lithological heterogeneity of the ophiolitic basement in the blueschist units implies to develop a renewed approch to the significance of the Schistes Lustrés nappes in general. Despite detailed studies in the $80-90 \mathrm{~s}$, which provided a comprehensive $3 \mathrm{D}$ view of the heterogeneous ultramafic seafloor, many authors have considered that the Schistes Lustrés nappes are the result of the offscrapping of the oceanic sediments and part of their basement incorportated within a giant accretionary prism. This interpretation implies that the oceanic domain sufferred a complete dismembering and that it is impossible to reconstruct any primary section of the oceanic basement. This paper provides a large pannel of field evidences demonstrating that detailed reconstruction of the oceanic basement of the Tethyan basement are possible. This approach could be conducted in numerous ophiolitic bodies in the Alpine-Appenine belt. We finally confirm that pristine oceanic heterogeneities may be preserved in internal oceanic units of collisional belts despite their tectonic and metamorphic evolution during subduction and subsequent exhumation.

\section{ACKNOWLEDGEMENTS}

We wish to thank our reviewers, Alessio Sanfilippo, Giancarlo Molli and Editor Carlo Doglioni, for their constructive remarks who greatly helped us to improve this manuscript.

\section{REFERENCES CITED}

Abbate E., Bortolotti V. and Passerini P., 1980. Apennine ophiolites: a peculiar oceanic crust. Ofioliti, 1: 59-96.

Agard, P., Jolivet, L., Goffé, B., 2001. Tectonometamorphic evolution of the Schistes Lustrés complex: implications for the exhumation of HP and UHP rocks in the western Alps, Bulletin de la Société Geologique de France, 172, 617-636. doi:10.2113/172.5.617

Ambrics C., and Bertrand, J., 1999 Petrological features of the Pelvas d'Abriès massif (northeastern Queyras, French-Italian Alps). Schweiz. Mineral. Petrogr. Mitt., 79, 431-437. doi:10.5169/seals-60217

Anonymous, 1972. Penrose field conference. Ophiolites. Geotimes, December 1972, 17, 2, 24-25.

Ballèvre M., Lagabrielle Y., Merle O., 1990. Tertiary ductile normal faulting as a consequence of lithospheric stacking in the western Alps, Mém. Soc. géol. Fr. 156 (1990) 227-236.

Ballèvre M., and Lagabrielle Y., 1994. Garnet in blueschist-facies marbles from the Queyras unit (Western Alps): its occurrence and its significace. Schweizerische und petrographishe Mineralogische Mitteilungen, 74, 203-212. doi:10.5169/seals-56342

Barrett, T.J., Spooner, E.T.C., 1977. Ophiolitic breccias associated with allochtonous oceanic crustal rocks in the East Ligurian Apennines, Italy - A comparison with observations from rifted oceanic ridges. Earth and Planetary Science Letters, 35, 79-91. doi:10.1016/0012$821 \mathrm{X}(77) 90031-0$ 
Bearth, P., Bocquet, J., Dal Piaz, G.V., Nervo, R. \& Polino, R., 1975. Structures de cumulat dans les ophiolites du Pelvas (Alpes franco-italiennes). confirmation d'une origine océanique. Pétrologie, 1, 3, 237-242.

Beccaluva L., Ohnenstetter D., Onenstetter M., Venturelli G., 1977. The trace element geochemistry of Corsican Ophiolites. Contrib Mineral Petrol 64:11-31

Beccaluva, L., Dal Piaz, G. V., and Macciotta, G., 1984. Transitional to MORB affinities in ophiolitic metabasites from the Zermatt-Saas, Combin and Antrona units, Western Alps: implication for the paleogeographic evolution of the Western Tethyan Basin. Geologie en Mijnbouw, 63, 165-177.

Beltrando, M., Manatschal, G., Mohn, G., Dal Piaz, G.V., Vitale Brovarone, A., Masini, E. (2014), Recognizing remnants of magma-poor rifted margins in high-pressure orogenic belts: The alpine case study, Earth Science Reviews, in press.

Bernouilli, D., Caron, C., Homewood, P., Kälin, O., Van Stuijvenberg, J., 1979. Evolution of continental margins in the Alps. Schweiz. mineral. petrogr. Mitt. , 59, 165-170.

Blackman, D.K., Ildefonse, B., John, B.E., Ohara, Y., Miller, D.J., MacLeod, C.J., and the Expedition 304/305 Scientists, 2006. Proc. IODP, 304/305: College Station TX (Integrated Ocean Drilling Program Management International, Inc.). doi:10.2204/iodp.proc.304305.2006

Blackman, D.K., Ildefonse, B., et al., 2011. Drilling constraints on lithospheric accretion and evolution at Atlantis Massif, Mid-Atlantic Ridge $30^{\circ} \mathrm{N}$. Journal of geophysical Research 116, B07103. doi:10.1029/2010JB007931

Boillot, G. and Froitzheim, N., 2001. Non-volcanic rifted margins, continental break-up and the onset of sea-floor spreading: some outstanding questions, in Wilson, R.C.L., et al. (Eds.), Nonvolcanic rifting of the Continental Margins: A comparison of Evidence from Land and Sea. Geological Society Special Publication 187, 9-30.

Boschi, C., Früh-Green, G.L., Delacour, A., Karson, J.A., Kelley, D.S., 2006. Mass transfer and fluid flow during detachment faulting and development of an oceanic core complex, Atlantis Massif (MAR 30N). Geochem. Geophys. Geosyst. 7, Q01004. doi:10.1029/2005GC001074

Caby, R., Michard, A., et Tricart, P., 1971. Découverte d'une brèche polygénique à éléments granitoïdes dans les ophiolites métamorphiques piémontaises (Schistes lustrés du Queyras, Alpes françaises). C. R. Acad. Sc. Paris, 273, 999-1002.

Caby, R. 1995. Plastic deformation of gabbros in a slow-spreading Mesozoic Ridge: example of the Montgenèvre Ophiolite R.L.M. Vissers, A. Nicolas (Eds.), Mantle and Lower Crust Exposed in Oceanic Ridges and in Ophiolites, Kluwer Academic Publishers (1995), pp. 123-145

Caby, R., 1996. Low-angle extrusion of high-pressure rocks and the balance between outward and inward displacements of Middle Penninic units in the western Alps. Eclogae Geologicae Helvetiae, 89(1), 229-267. doi:10.5169/seals-167901

Cann, J.R., Blackman, D.K., Smith, D.K., McAllister, E., Janssen, B., Mello, S., Avgerinos, E., Pascoe, A.R., Escartín, J., 1997. Corrugated slip surfaces formed at ridge-transform intersections on the Mid-Atlantic Ridge. Nature 385, 329-332. doi:10.1038/385329a0

Cannat, M., Mével, C., Maia, M., Deplus, C., Durand, C., Gente, P., Agrinier, P., Belarouchi, A., Dubuisson, G., Humler, E., and Reynolds, J., 1995a. Thin crust, ultramafic exposures, and rugged faulting pattern at the Mid-Atlantic Ridge $\left(22^{\circ}-24^{\circ} \mathrm{N}\right)$. Geology, v. 23, p. 49-52. doi:10.1130/0091-7613(1995)023<0049:TCUEAR >2.3.CO;2

Cannat, M., Karson, J.A., Miller, D.J., et al., 1995b. Proc. ODP, Init. Repts, 153: College Station, TX (Ocean Drilling Program). doi:10.2973/odp.proc.ir.153.1995

Cannat, M., Sauter, D., Mendel, V., Ruellan, E., Okino, K., Escartin, J., Combier, V., Baala, M., 2006. Modes of seafloor generation at a melt-poor ultraslow-spreading ridge: Gelology, 34, 605-608. doi:10.1130/G22486.1

Caron, J.M., Delcey, R., 1979. Lithostratigraphie des schistes lustrés corses: diversité des séries post-ophiolitiques. Comptes Rendus de l'Académie des Sciences Paris 208, $1525-1528$.

Carpéna, J., Caby, R., 1984. Fission-track evidence for late Triassic oceanic crust in the French Occidental Alps. Geology, 12, 108-111. 
Chopin, C., 1984. Coesite and pure pyrope in high-grade blueschists of the Western Alps: a first record and some consequences. Contrib. Mineral. Petrol. 86, 107-118. doi:10.1007/BF00381838

Cliff, R.A., Barnicoat, A.C., Inger, S., 1998. Early Tertiary eclogite facies metamorphism in the Monviso Ophiolite. J. Metamorph. Geol. 16, 447-455.

Cortesogno L., Gianelli G. and Piccardo G.B., 1975. Pre-orogenic metamorphic and tectonic evolution of the ophiolite mafic rocks (Northern Apennines and Tuscany). Boll. Soc.Geol. It., 94: 291-321.

Cortesogno, L., Galbiati, B., Principi, G., and Venturelli, G., 1978. La brecce ofiolitiche della liguria orientale: nuovi dati e discussione sui modelli paleogeografici. Ofioliti, 3, 99-160.

Cortesogno L., Gaggero L., Molli G. 1996. Ocean floor metamorphism in the Piedmont-Ligurian Jurassic basin: a review. Mem. Soc. Geol. It. 48, 151-163.

de Wever, P., Caby, R., 1981. Datation de la base des schistes lustrés postophiolitiques par des radiolaires (Oxfordien supérieur-Kimméridgien) dans les Alpes cotiennes (Saint-Véran, France). C. R. Acad. Sc. Paris, 292, II, 467-472.

de Wever, P., Baumgartner, P. O., and Polino, R., 1987. Précision sur la datation de la base de Schistes lustrés post-ophiolitiques dans les Alpes Cottiennes. C. R. Acad. Sci. Paris, 305, II, 487-491.

deMartin, B.J., Sohn, R.A., Pablo Canales, J., Humphris, S.E., 2007. Kinematics and geometry of active detachment faulting beneath the Trans-Atlantic Geotraverse (TAG) hydrothermal field on the Mid-Atlantic Ridge. Geology 35, 711. doi:10.1130/G23718A.1

Decandia, A. and Elter, P., 1969. Riflessioni sul problema delle ofioliti dell'Appennino settentrionale (nota preliminare). Atti Soc. Tosc. Sc. Nat., Mem., Ser. A, 76.

Decandia, A. and Elter P., 1972. La zona ofiolitifera del Bracco nel settore compreso fra Levanto e la Val Graveglia (Appennino Ligure). Soc. Geol. It., Mem., 11, 503-530.

Desmurs, L., Manatschal, G., and Bernoulli, D., 2001. The Steinmann Trinity revisited: mantle exhumation and magmatism along an ocean-continent transition: the Platta nappe, eastern Switzerland. Geological Society, London, Special Publications, 187:235-266, doi:10.1144/GSL.SP.2001.187.01.12

Desmurs, L., O. Müntener, G. Manatschal. 2002. Onset of magmatic accretion within a magma-poor rifted margin: a case study from the Platta ocean-continent transition, eastern Switzerland Contributions to Mineralogy and Petrology, 144 (2002), pp. 365-382

Deville E., Fudral S., Lagabrielle Y., Marthaler M. and Sartori M., 1991. From oceanic closure to continental collision: A synthesis of the "Schistes lustrés" metamorphic complex of the Western Alps. Geol. Soc. Am. Bull., 104: 127-139.

Dick, H.J.B., Natland, J.H., Alt, J.C., Bach, W., Bideau, D., Gee, J.S., Haggas, S., Hertogen, J.G.H., Hirth, G., Holm, P.M., ildefonse, B., Iturrino, G.J., John, B.E., Kelley, D.S., Kikawa, E., Kingdon, A., LeRoux, P.J., Maeda, J., Meyer, P.S., Miller, D.J., Naslund, H.R., Niu, Y.-L., Robinson, P.T., Snow, J., Stephen, R.A., Trimby, P.W., Worm, H.-U., Yoshinobu, A., 2000. A long in situ section of the lower ocean crust: results of ODP Leg 176 drilling at the Southwest Indian Ridge. Earth and Planetary Science Letters 179, 31-51. doi:10.1016/S0012$821 \mathrm{X}(00) 00102-3$

Dick, H.J.B., Tivey, M.A., Tucholke, B.E., 2008. Plutonic foundation of a slow-spreading ridge segment: Oceanic core complex at Kane Megamullion, $23^{\circ} 30^{\prime} \mathrm{N}, 45^{\circ} 20^{\prime} \mathrm{W}$. Geochem. Geophys. Geosyst. 9, Q05014. doi:10.1029/2007GC001645

Drouin, M., Godard, M., Ildefonse, B., Bruguier, O., Garrido, C.J., 2009. Geochemical and petrographic evidence for magmatic impregnation in the oceanic lithosphere at Atlantis Massif, Mid-Atlantic Ridge (IODP Hole U1309D, 30 N). Chemical Geology, 264, 71-88. doi:10.1016/j.chemgeo.2009.02.013

Drouin, M., ildefonse, B., Godard, M., 2010. A microstructural imprint of melt impregnation in slow spreading lithosphere: Olivine-rich troctolites from the Atlantis Massif, Mid-Atlantic Ridge, 30 degrees N, IODP Hole U1309D. Geochem. Geophys. Geosyst. 11, Q06003. doi:10.1029/2009GC002995 
Duchêne, S., Bilchert-Toft, J., Luais, B., Telouk, P., Lardeaux, J. M., Albarede, F., 1997. The Lu-Hf dating of garnets and the ages of the Alpine high-pressure metamorphism. Nature 387:586589.

Durand-Delga, M., 1978. Corse. Guides géologiques régionaux., Masson, Pa. ed., 208.

Elter, P., 1972. La zone ofiolitifera del Bracco nel quadro dell'Appennino settentrionale. Guida alle escursioni. 66 ${ }^{\circ}$ Congr. Soc. Geol. It., Pisa-Genova Settembre 1972.

Escartín, J., Canales, J.P., 2011. Detachments in oceanic lithosphere: Deformation, magmatism, fluid flow, and ecosystems. Eos Trans. AGU 92, 31. doi:10.1029/2011EO040003

Escartín, J., Mével, C., MacLeod, C.J., McCaig, A.M., 2003. Constraints on deformation conditions and the origin of oceanic detachments: The Mid-Atlantic Ridge core complex at $15^{\circ} 45^{\prime} \mathrm{N}$. Geochemistry Geophysics Geosystems, 4(8). doi:10.1029/2002GC000472

Escartín, J., D. K. Smith, J. R. Cann, H. Schouten, C. H. Langmuir, and S. Escrig, 2008. Central role of detachment faults in accretion of slow-spreading oceanic lithosphere, Nature, 455, 790-794, doi:10.1038/nature07333.

Froitzheim, N., and Manatschal, G., 1996. Kinematics of Jurassic rifting, mantle exhumation, and passive-margin formation in the Austroalpine and Penninic nappes (eastern Switzerland). Geol. Soc. Am. Bull., 108(9):1120-1133.

Gebauer, D.; Schertl, H. P.; Brix, M.; and Schreyer, W. 1997. 35 Ma old ultrahigh-pressure metamorphism and evidence for very rapid exhumation in the Dora Maira Massif, Western Alps. Lithos 41:5-24.

Gianelli, G., 1977. Vara supergroup ophiolite probably represents an ancient transcurrent fault zone. Ofioliti, 2 115-135

Gianelli, G., Principi, G., 1977. Northern Appennine ophiolite: An ancient transcurrent fault zone. Società Geologica Italiana, Bolletino, 96, 53-58.

Godard, M., Awaji, S., Hansen, H., Hellebrand, E., Brunelli, D., Johnson, K., Yamasaki, T., Maeda, J., Abratis, M., Christie, D., Kato, Y., Mariet, C., Rosner, M., 2009. Geochemistry of a long in-situ section of intrusive slow-spread oceanic lithosphere: Results from IODP Site U1309 (Atlantis Massif, $30^{\circ} \mathrm{N}$ Mid-Atlantic-Ridge). Earth and Planetary Science Letters 279, 110122. doi:10.1016/j.epsl.2008.12.034

Grimes, C.B., John, B.E., Cheadle, M.J., Wooden, J.L., 2008. Protracted construction of gabbroic crust at a slow spreading ridge: Constraints from $206 \mathrm{~Pb} / 238 \mathrm{U}$ zircon ages from Atlantis Massif and IODP Hole U1309D (30N, MAR). Geochem. Geophys. Geosyst. 9, Q08012. doi:10.1029/2008GC002063

Handy, M.R., Schmid, S.M., Bousquet, R., Kissling, E., Bernoulli, D. (2010): Reconciling platetectonic reconstructions with the geological-geophysical record of spreading and subduction in the Alps. Earth Science Reviews, 102, 121-158.

Ildefonse, B., Blackman, D.K., John, B.E., Ohara, Y., Miller, D.J., MacLeod, C.J., 2007a. Oceanic core complexes and crustal accretion at slow-spreading ridges. Geology 35, 623-626. doi:10.1130/G23531A.1

Ildefonse, B., Rona, P., Blackman, D., 2007b. Drilling the Crust at Mid-Ocean Ridges: An "In Depth" Perspective. Oceanography 20, 66-77. doi:10.5670/oceanog.2007.81

John, B.E., Cheadle, M.J., Gee, J.S., Grimes, C.B., Morris, A., and Pressling, N., 2009. Data report: spatial and temporal evolution of slow spread oceanic crust-graphic sections of core recovered from IODP Hole U1309D, Atlantis Massif, 30 ${ }^{\circ} \mathrm{N}$, MAR (including $\mathrm{Pb} / \mathrm{U}$ zircon geochronology and magnetic remanence data). In Blackman, D.K., Ildefonse, B., John, B.E., Ohara, Y., Miller, D.J., MacLeod, C.J., and the Expedition 304/305 Scientists, Proc. IODP, 304/305: College Station, TX (Integrated Ocean Drilling Program Management International, Inc.). doi:10.2204/iodp.proc.304305.205.2009

Juteau, T., Berger, E. and Cannat, M., 1990a. Serpentinized, residual mantle peridotites from the MAR median valley, ODP hole $670 \mathrm{a}\left(21^{\circ} 10^{\prime} \mathrm{N}, 45^{\circ} 02^{\prime} \mathrm{W}\right.$, leg 109): preliminary mineralogy and geothermometry. In Detrick, R., Honnorez, J., Bryan, W.B., Juteau, T., et al., Proc. ODP, Sci. Results, 106/109: College Station, TX (Ocean Drilling Program), 27-45. doi:10.2973/odp.proc.sr.106109.117.1990

Juteau, T., Cannat, M., and Lagabrielle, Y. 1990b. Serpentinized peridotites in the upper oceanic crust away from transform zones: a comparison of the results of previous DSDP and ODP legs. In 
Detrick, R., Honnorez, J., Bryan, W.B., Juteau, T., et al., Proc. ODP, Sci. Results, 106/109: College Station, TX (Ocean Drilling Program), 303-308. doi:10.2973/odp.proc.sr.106109.162.1990

Karson, J.A., 1990. Seafloor spreading on the Mid-Atlantic Ridge: implications for the structure of ophiolites and oceanic lithosphere produced in slow-spreading environments. In Malpas, J., Moores, E.M., Panayiotou, A., and Xenophontos, C. (Eds.), Ophiolites: Oceanic Crustal Analogues: Proc. Symp. "Troodos 1987": Nicosia, Cyprus (Minist. Agric. Nat. Resour.), 547555.

Karson, J. A., and Lawrence, R.M., 1997a. Tectonic setting of serpentinite exposures on the western median valley wall of the MARK area in the vicinity of ODP Site 920. In J. Karson, M. Cannat, J. Miller and D. Elthon (Eds.), Proc. ODP, Sci. Results, 153: College Station, TX, (Ocean Drilling program), 5-21. doi:10.2973/odp.proc.sr.153.001.1997

Karson, J.A., and Lawrence, R.M., 1997b Tectonic window into gabbroic rocks of the middle oceanic crust in the MARK area near ODP Sites 921-924. In J. Karson, M. Cannat, J. Miller and D. Elthon (Eds.), Proc. ODP, Sci. Results, 153: College Station, TX, (Ocean Drilling program), 6176. doi:10.2973/odp.proc.sr.153.005.1997

Karson, J.A., Früh-Green, G.L., Kelley, D.S., Williams, E.A., Yoerger, D.R., and Jakuba, M. 2006. Detachment shear zone of the Atlantis Massif core complex, Mid-Atlantic Ridge, $30^{\circ} \mathrm{N}$. Geochem. Geophys. Geosystems. 7, 6, Q06016, doi : 10. 1029/20O5GC001109.

Kelemen, P.B., Kikawa, E., Miller, D.J., Shipboard Scientific Party, 2007. Leg 209 summary: processes in a $20-\mathrm{km}$-thick conductive boundary layer beneath the Mid-Atlantic Ridge, $14^{\circ}-$ $16^{\circ}$ N. In: Kelemen, P.B., Kikawa, E., and Miller, D.J. (Eds.), Proc. ODP, Sci. Results, 209. College Station, TX (Ocean Drilling Program) 209, 1-33. doi:10.2973/odp.proc.sr.209.001.2007

Lafay, R., Deschamps, F., Schwartz, S., Guillot, S., Godard, M., Debret, B., Nicollet, C., 2013. High-pressure serpentinites, a trap-and-release system controlled by metamorphic conditions: Example from the Piedmont zone of the western Alps. Chemical Geology 343, 38-54. doi:10.1016/j.chemgeo.2013.02.008

Lagabrielle, 1987. Les ophiolites: Marqueurs de l'histoire tectonique des domaines océaniques. Thesis, Univ. Brest, France, $350 \mathrm{p}$.

Lagabrielle Y., 1994. Ophiolites of the Western Alps and the nature of the Tethyan oceanic lithosphere. Ofioliti. 19, 2b, 413-434. (paru en 1996)

Lagabrielle, Y., 2009. Mantle exhumation and lithospheric spreading: An historical perspective from investigations in the Oceans and in the Alps-Apennines ophiolites., Ital.J.Geosci. (Boll.Soc.Geol.It.), Sezione Tematica su Alps and Apennines Vol. 128, No. 2 (2009), pp. 279293. doi:10.3301/IJG.2009.128.2.279)

Lagabrielle, Y., Polino, R., Auzende, J.M., Blanchet, R., Caby, R., Fudral, F., Lemoine, M., Mével, C. Ohnenstetter, M., Robert, D., and Tricart, P., 1984. Les témoins d'une tectonique intraocéanique dans le domaine téthysien: analyse des rapports entre les ophiolites et leur couverture métasédimentaire dans la zone piémontaise des Alpes franco-italiennes. Ofioliti, 9, 67-88.

Lagabrielle, Y., Lemoine, M. \& Tricart, P., 1985. Paléotectonique océanique et déformations alpines dans le massif ophiolitique du Pelvas d'Abriès (Alpes Occidentales - Queyras - France). Bull. Soc. géol. Fr., (8), t. I, 4, p. 473-479.

Lagabrielle, Y. \& Polino, R., 1985 .- Origine volcano-détritique de certaines prasinites des Schistes lustrés du Queyras (France) : arguments texturaux et géochimiques. Bull. Soc. géol. Fr., (8), t. I, 4, p. 461-471.

Lagabrielle, Y. et Polino, R., 1988 .- Un schéma structural du domaine des Schistes lustrés ophiolitifères au nord-ouest du massif du Mont Viso (Alpes sud-occidentales) et ses implications. C.R. Acad. Sci. Paris, t. 306, Série II, p. 921-928.

Lagabrielle Y. and Cannat M., 1990. Alpine jurassic ophiolites resemble the modern central atlantic basement. Geology, 18: 319-322.

Lagabrielle, Y. and Lemoine, M., 1997. Alpine, Corsican and Apennine ophiolites : the slow spreading ridge model. Concise review paper. C.R. Acad. Sc. Paris, 325, 909-920. 
Lagabrielle, Y., Bideau, D., Cannat, M., Karson, K.A., and Mével, C., 1998. Ultramafic-mafic plutonic rock suites exposed along the Mid-Atlantic Ridge $\left(10^{\circ} \mathrm{N}-30^{\circ} \mathrm{N}\right)$. Symmetricalasymmetrical distribution and implications for seafloor spreading processes. In, Faulting and Magmatism at Mid-Oceanic Ridges Proceedings of the 4th RIDGE Theoretical Institute, American Geophysical Union, W.R. Buck, J.A. Karson, P.A. Delaney, and Y. Lagabrielle eds., Geophysical Monograph 106, pp. 154-176.

Le Mer, O., Lagabrielle, Y. et Polino, R., 1986 .- Une série sédimentaire détritique liée aux Ophiolites piémontaises : analyses lithostratigraphiques, texturales et géochimiques dans le massif de la Crête de Mouloun (Haut-Queyras, Alpes sud-occidentales, France). Géologie Alpine, t. 62, p. 63-86.

Lemoine, M., Steen, D., et Vuagnat, M., 1970. Sur le problème des ophiolites piémontaises et des roches sédimentaires associées : observations dans le massif de Chabrière en Haute-Ubaye. $C$. $R$. des Séances, SPHN Genève, NS, 5, 1, 44-59.

Lemoine, M., 2003. Schistes lustrés from Corsica to Hungary : back to the original sediments. Bull. Soc. géol. Fr., 2003, t. 174, no 3, pp. 197-209

Lemoine, M., Tricart, P., 1986. Les schistes lustrés piémontais des Alpes occidentales : approche stratigraphique, structurale et sédimentologie. Eclogae geol. helv., 79, 271-294.

Lemoine, M., Marthaler, M., Caron, M., Sartori, M., Amaudric du Chaffaut, S., et al., 1984. Découverte de foraminifères planctoniques du Crétacé supérieur dans les schistes lustrés du Queyras (Alpes occidentales). Conséquences paléogéographiques et tectoniques. C. R. Acad. Sc. Paris, 299, 727-732.

Lemoine M., Boillot G. and Tricart P., 1987. Ultramafic and gabbroic ocean floor of the Ligurian Tethys (Alps, Corsica, Apennines): In search of a genetic model. Geology, 15: 622-625.

Lemoine, M., Trümpy, R., 1987. Pre-oceanic rifting in the Alps. Tectonophysics, 133, 305-320.

Levi, N., Malasoma, A., Marroni, M., Pandolfi, L., Paperini, M., 2007. Tectono-metamorphic history of the ophiolitic Lento unit (northern Corsica): evidences for the complexity of accretionexhumation processes in a fossil subduction system. Geodinamica Acta 20, 99-118. doi:10.3166/ga.20.99-118

Lombardo B. and Pognante U., 1982. Tectonic implications in the evolution of the western Alps ophiolite metagabbro. Ofioliti, 7, 2/3: 371-394.

MacLeod, C.J., Escartin; J., Banerji, D., Banks, G.J., Gleeson, M., Irving, D.H.B., Lilly, R.M., McCaig, A.M., Niu, Y, Allerton,S. and Smith, D.K. 2002. Direct geological evidence for oceanic detachment faulting: The Mid-Atlantic Ridge, $15^{\circ} 45^{\prime}$ N. Geology, 30, 879-882. doi:10.1130/0091-7613(2002)030<0879:DGEFOD > 2.0.CO;2

MacLeod, C.J., Searle, R.C., Murton, B.J., Casey, J.F., Mallows, C., Unsworth, S.C., Achenbach, K.L., Harris, M., 2009. Life cycle of oceanic core complexes. Earth and Planetary Science Letters 287, 333-344. doi:10.1016/j.eps1.2009.08.016

Manatschal, G., and Nievergelt, P., 1997. A continent-ocean transition recorded in the Err and Platta nappes (eastern Switzerland). Eclogae Geol. Helv., 90:3-27.

Manatschal, G. and Müntener, O., 2009. A type sequence across and ancient magma-poor oceancontinent transition: the example of the western Alpine Tehthys ophiolites. Tectonophysics, (doi:10.1016/j.tecto.2008.07.021)

Manatschal, G., Sauter D., Karpoff A.M., Masini E., Mohn G., Lagabrielle Y., 2011. The Chenaillet Ophiolite in the French/Italian Alps: An ancient analogue for an Oceanic Core Complex?, Lithos, 124, 169-184. doi:10.1016/j.lithos.2010.10.017

Masini, E., Manatschal, G., Mohn, G., 2013. The Alpine Tethys rifted margins: reconciling old and new ideas to understand the stratigraphic architecture of magma-poor rifted margins. Sedimentology 60, 174-196. doi:10.1111/sed.12017.

Marroni M., Molli G., Ottria G. and Pandolfi L. (2001). Tectono-sedimentary evolution of the External Liguride Units (Northern Apennine, Italy): from rifting to convergence history of a fossil ocean-continent transition zone. Geodinamica Acta, 14 (4): 307-320.

Marroni, M., Molli, G., Montanini, A. and Tribuzio, R. (1998): The association of continental crust rocks with ophiolites in the Northern Apennines (Italy); implications for the continent-ocean transition in the western Tethys. Tectonophysics, 292(1-2): 43-66. 
Marthaler, M., Fudral, S., Deville, E., et Rampnoux, J. P., 1986. Mise en évidence du Crétacé supérieur dans la couverture septentrionale de Dora Maira, région de Suse, Italie (Alpes occidentales). Conséquences paléogéographiques et structurales. C. R. Acad. Sc. Paris,302, II, 91-96.

McCaig, A.M., Harris, M., 2012. Hydrothermal circulation and the dike-gabbro transition in the detachment mode of slow seafloor spreading. Geology 40, 367-370. doi:10.1130/G32789.1

Meresse, F., Lagabrielle, Y., Malavieille, J., and Ildefonse, B., 2012. A fossil Ocean-Continent Transition of the Mesozoic Tethys preserved in the Schistes Lustrés nappe of northern Corsica. Tectonophysics, 579, 4-16. doi:10.1016/j.tecto.2012.06.013

Menna, F., Principi, G., Treves, B., Podetti, S., Garfagnoli, F., Corti, S., 2007. The pre-orogenic tectonic history of the Bracco gabbroic massif: review and news. Periodico di Mineralogia 76, 81-100. doi:10.2451/2007PM0010

Mével, C., Cannat, M., Gente, P., Marion, E., Auzende, J.-M. and Karson, J.A. 1991. Emplacement of deep crustal and mantle rocks on the west median valley wall of the MARK area (MAR, $23^{\circ} \mathrm{N}$ ), Tectonophysics, 190, 31-53. doi:10.1016/0040-1951(91)90353-T

Molli G.1995. Pre-orogenic high temperature shear zones in an ophiolite complex (Bracco Massif Northern Apennine, Italy). In R.L.M. Vissers and A. Nicolas eds. "Mantle and lower crust exposed in oceanic ridges and ophiolites". Kluwer Acad.Publ., 147-161.

Molli G. 1996. Pre-orogenic tectonic framework of the Northern Apennine ophiolites. Eclogae geol. Helv. 89/1: 163-180.

Monié, P., and Philippot, P. 1989. Mise en e évidence de l'âge éocène moyen du métamorphisme de haute-pression dans la nappe ophiolitique du Monviso (Alps Occidentales) par la méthode ${ }^{40} \mathrm{Ar} /{ }^{39}$ Ar. C. R. Acad. Sci. Paris, 309:245-251.

Ohara, Y., Yoshida, T., Kato, Y., Kasuga, S., 2001. Giant megamullion in the Parece Vela backarc basin. Marine Geophysical Research 22, 47-61.

Ohara, Y., Fujioka, K., Ishii, T., Yurimoto, H., 2003. Peridotites and gabbros from the Parece Vela backarc basin: Unique tectonic window in an extinct backarc spreading ridge. Geochem. Geophys. Geosyst. 4, 7, 8611. doi:10.1029/2002GC000469

Olive, J.-A., Behn, M.D., Tucholke, B.E., 2010. The structure of oceanic core complexes controlled by the depth distribution of magma emplacement. Nature Publishing Group 3, 491-495. doi:10.1038/ngeo888

Ohnenstetter, M.E., Ohnenstetter, D., Vidal, P., Cornichet, J., Hermitte, D., Mace, J., 1981. Cristallization and age of zircon from Corsican ophiolitic albitites: consequences for oceanic expansion in Jurassic time. Earth and Planetary Science Letters 54, 397-408

Picazo, S., Cannat, M., Delacour, A., Escartín, J., Rouméjon, S., Silantyev, S., 2012. Deformation associated with the denudation of mantle-derived rocks at the Mid-Atlantic Ridge $13^{\circ}-15^{\circ} \mathrm{N}$ : The role of magmatic injections and hydrothermal alteration. Geochem. Geophys. Geosyst. 13, Q04G09. doi:10.1029/2012GC004121

Piccardo, G.B., Guarnieri, L., 2010. Alpine peridotites from the Ligurian Tethys: an updated critical review. International Geology Review 52, 1138-1159.

Piccardo, G.B., 1977. Le ofioliti dell' areale ligure: petrologia e ambiante geodinamico di formazione. Rendiconti della Società Italaliana di Mineralogia e Petrologia, 33, 221-252.

Pinet, N., Lagabrielle, Y., and Whitechurch, H., 1989. Le complexe du Pic des Lauzes (Haut Queyras, Alpes Occidentales, France) : structures alpines et océaniques dans un massif ophiolitique de type liguro-piémontais. Bull. Soc. géol. Fr.,2, p. 317-326.

Pognante, U., Perotto, A., Salino, C., and Toscani, L., 1986. The ophiolitic peridotite of the western Alps: Record of the evolution of a small oceanic-type basin in the Mesozoic Tethys. Tschermaks Mineralogische und Petrographische Mitteilungen, 35, 47-65.

Polino, R., Lemoine, M., 1984. Détritisme mixte d'origine continentale et océanique dans les sédiments jurassico-crétacés supra-ophiolitiques de la Téthys ligure : la série du Lago Nero (Alpes occidentales franco-italiennes). Cr. Acad. Sci. Paris , 298, II, 8, 359-364.

Principi, G., Bortolotti, V., Chiari, M., Cortesogno, L., Gaggero, L., Marcucci, M., Saccani, E., Treves, B., 2004. The pre-orogenic volcano-sedimentary covers of the western Tethys oceanic basin: a revue.. OFIOLITI, vol. 29 (2), pp. 177-211. 
Rampone, E., Hofmann, A.W., Raczek, I., 2009. Earth and Planetary Science Letters. Earth and Planetary Science Letters 288, 601-610.

Ravna, E.J.K., Andersen, T.B., Jolivet, L., de Capitani, C., 2010. Cold subduction and the formation of lawsonite eclogite - constraints from prograde evolution of eclogitized pillow lava from Corsica 28, 381-395.

Renna, M.R., Tribuzio, R., 2011. Olivine-rich Troctolites from Ligurian Ophiolites (Italy): Evidence for Impregnation of Replacive Mantle Conduits by MORB-type Melts. Journal of Petrology 52, 1763-1790. doi:10.1093/petrology/egr029

Reston, T.J., Ranero, C.R., 2011. The 3-D geometry of detachment faulting at mid-ocean ridges. Geochem. Geophys. Geosyst. 12, Q0AG05. doi:10.1029/2011GC003666

Reston, T.J., Weinrebe, W., Grevemeyer, I., Flueh, E.R., Mitchell, N.C., Kirstein, L., Kopp, C., Kopp, H., and Participants of Meteor 47/2, 2002. A rifted inside corner massif on the MidAtlantic Ridge at $5^{\circ} \mathrm{S}$. Earth and Planetary Science Letters, 200(3-4), 255-269. doi:10.1016/S0012-821X(02)00636-2

Ricou, L. E., Zonenshain, P., Dercourt, J., Kazmin, V. G., Le Pichon, X., Knipper, L., et al., 1985. Méthodes pour l'établissement de neuf cartes paléographiques de l'Atlantique au Pamir depuis le Lias. Bull. Soc. géol. Fr., 5, 625-635.

Rossi, P., Durand-Delga, M., COLL, A., 2002. Carte géol. France (1/50000), feuille Santo Pietro di Tenda (1106). Orléans: BRGM.

Rubatto, D., \& Hermann, J. (2001). Exhumation as fast as subduction? Geology, 29(1), 3-6. doi:10.1130/0091-7613(2001)

Saccani, E., Principi, G., Garfagnoli, F., Menna, F., 2008. Corsica ophiolites: geochemistry and petrogenesis of basaltic and metabasaltic rocks. Ofioliti 33, 187-207.

Sanfilippo, A., and R. Tribuzio (2011), Melt transport and deformation history in a nonvolcanic ophiolitic section, northern Apennines, Italy: Implications for crustal accretion at slow spreading settings, Geochem. Geophys. Geosyst., 12, Q0AG04, doi:10.1029/2010GC003429).

Sanfilippo, A., and Tribuzio, R., 2013a. Building of the deepest crust at a fossil slow-spreading centre (Pineto gabbroic sequence, Alpine Jurassic ophiolites). Contributions to Mineralogy and Petrology, 165(4), 705-721. doi:10.1007/s00410-012-0831-8

Sanfilippo, A., and Tribuzio, R., 2013b. Origin of olivine-rich troctolites from the oceanic lithosphere: a comparison between the alpine Jurassic ophiolites and modern slow spreading ridges. Ofioliti 38, 89-99. doi:10.4454/ofioliti.v38i1.418

Sauter, D., Cannat, M., Rouméjon, S., Andreani, M., Birot, D., Bronner, A., Brunelli, D., Carlut, J., Delacour, A., Guyader, V., MacLeod, C.J., Manatschal, G., Mendel, V., Ménez, B., Pasini, V., Ruellan, É., Searle, R., 2013. Continuous exhumation of mantle-derived rocks at the Southwest Indian Ridge for 11 million years. Nature Geoscience, 6, 314-320. doi:10.1038/ngeo1771

Schaaf, A., Polino, R., and Lagabrielle, Y., 1985. Nouvelle découverte de Radiolaires d'âge Oxfordien supérieur-Kimméridgien inférieur, à la base d'une série supraophiolitique des schistes lustrés piémontais (Massif de Traversiera, Haut Val Maira, Italie). C.R. Acad. Sc. Paris, 301, II, 14, 1079-1084.

Schmid, S.M., Fügenschuh, B., Kissling, E., Schuster, R., 2004. Tectonic Map and overall architecture of the Alpine orogen. Eclogae Geologicae Helvetiae 97 (1), 93-117.

Schroeder, T., John, B.E., 2004. Strain localization on an oceanic detachment fault system, Atlantis Massif, $30^{\circ} \mathrm{N}$, Mid-Atlantic Ridge. Geochem. Geophys. Geosyst. 5, Q11007. doi:10.1029/2004GC000728

Schwartz, S., Lardeaux, J. M., Guillot, S., \& Tricart, P. (2000). Diversité du métamorphisme éclogitique dans le massif ophiolitique du Monviso (Alpes occidentales, Italie). Geodinamica Acta, 13(2), 169-188. doi:10.1016/S0985-3111(00)00112-1

Schwartz, 2001. La zone piémontaise des Alpes occidentales : un paléo-complexe de subduction; arguments métamorphiques, géochronologiques et structuraux. Documents du BRGM, vol. $302,313 p$. 
Schwartz S., Lardeaux J.M., Tricart P., Guillot S., Labrin E., 2007. Diachronous exhumation of HPLT rocks from southwestern Alps : evidence from fission-track analysis. Terra Nova, vol. 19 (2), pp. 1-8. doi:10.1111/j.1365-3121.2006.00728.x

Schwartz, S., Guillot, S., Reynard, B., Lafay, R., Nicollet, C., Debret, B., Lanari, P., Auzende, A.L., 2012. Pressure-temperature estimates of the lizardite/antigorite transition in high pressure serpentinites. LITHOS, 178, 197-210.

Smith, D.K., Cann, J.R., Escartín, J., 2006. Widespread active detachment faulting and core complex formation near $13^{\circ} \mathrm{N}$ on the Mid-Atlantic Ridge. Nature 442, 440-443. doi:10.1038/nature04950

Searle, R.C., 2003. FUJI Dome: A large detachment fault near $64^{\circ} \mathrm{E}$ on the very slow-spreading southwest Indian Ridge. Geochem. Geophys. Geosyst. 4, 9105. doi:10.1029/2003GC000519

Sedan, O., 1983. Étude cartographique et structurale d'un secteur de la Corse Alpine. La zone de la nappe des schistes lustrés (canton de Morosaglia). $\mathrm{PhD}$ thesis, Univ. Marseille.

Smith, D.K., Escartín, J., Schouten, H., \& Cann, J.R., 2008. Fault rotation and core complex formation: Significant processes in seafloor formation at slow-spreading mid-ocean ridges (Mid-Atlantic Ridge, $13^{\circ}-15^{\circ} \mathrm{N}$ ). Geochemistry Geophysics Geosystems, 9(3), Q03003. doi:10.1029/2007GC001699

Stampfli, G.M., Mosar, J., Marquer, D., Marchant, R., Baudin, T., Borel, G., 1998. Subduction and obduction processes in the Swiss Alps. Tectonophysics 296, 159-204.

Suhr, G., Hellebrand, E., Johnson, K., Brunelli, D., 2008. Stacked gabbro units and intervening mantle: A detailed look at a section of IODP Leg 305, Hole U1309D. Geochem. Geophys. Geosyst. 9, Q10007. doi:10.1029/2008GC002012

Tilton, G. R.; Schreyer, W.; and Schertl, H. P. 1991. Pb- Sr-Nd isotopic behaviour of deeply subducted crustal rocks from the Dora Maira massif, Western Alps, Italy. II. What is the age of the ultra-high pressure meta- morphism? Contrib. Mineral. Petrol. 108:22-33.

Tribuzio R., Molli G., Riccardi M.P. \& Messiga B. 1997. Retrograde metamorphism in ophiolitic gabbros from Bonassola (Northern Apennines): a record of the Ligurian Tethys Oceanization. In: Continental rifting to ocean-floor metamorphism. Messiga B. \& Gosso G. eds., International Ophiolite Symposium, Ofioliti, 22(1), 163-174.

Tribuzio, R., Tiepolo, M., Vannucci, R., \& Bottazzi, P., 1999. Trace element distribution within olivine-bearing gabbros from the Northern Apennine ophiolites (Italy): evidence for postcumulus crystallization in MOR-type gabbroic rocks. Contributions to Mineralogy and Petrology, 134(2-3), 123-133.

Tribuzio, R., Tiepolo, M., \& Vannucci, R., 2000. Evolution of gabbroic rocks of the Northern Apennine ophiolites (Italy): comparison with the lower oceanic crust from modern slowspreading ridges. SPECIAL PAPERS-GEOLOGICAL SOCIETY OF AMERICA, 129-138.

Tricart P. and Lemoine M., 1983. Serpentinite oceanic bottom in South Queyras ophiolites (French Western Alps): record of the incipient oceanic opening of the mesozoic ligurian Tethys. Ecl. geol. helv., 76, 3: 611-629.

Tricart, P., Gout, C., et Lemoine, M., 1985. Mosaïque de blocs faillés et injection de serpentinites dans la croûte océanique téthysienne : l'exemple des ophiolites de Chabrière (Haute Ubaye, zone piémontaise des Alpes occidentales). C. R. Acad. Sc. Paris, 300, 817-820.

Tricart, P., Lemoine, M., 1986. Mégaboudinage alpin et fracturation téthysienne dans les schistes lustrés piémontais à l'Ouest du Mont Viso (Alpes occidentales). C. R. Acad. Sc. Paris, 302, 599-604.

Tricart P. and Lemoine M., 1991. The Queyras ophiolite west of Monte Viso (Western Alpes): indicator of a peculiar ocean floor in the Mesozoic Tethys. J. Geodynamics, 13, 163-181;

Tricart, P., Amaudric du Chaffaut, S., Ayoub, C., Ballèvre, M., Caby, R., Gout, C, Lagabrielle, Y., Leblanc, C., Le Mer, O., Philippot, P., Saby, P. (2003). Carte géol. France (1/50 000), feuille Aiguilles-Col Saint-Martin (848). Orléans, BRGM, Notice explicative par Tricart et al., (2003), $150 \mathrm{p}$.

Tucholke, B.E., Lin, J., 1994. A geological model for the structure of ridge segments in slow spreading ocean crust. Journal of geophysical Research 99, 11937. doi:10.1029/94JB00338 
Tucholke, B. E., Lin, J., and Kleinrock, M. C., 1998. Megamullions and mullion structure defining oceanic metamorphic core complexes on the Mid-Atlantic Ridge. Journal of Geophysical Research, 103(B5), 9857-9866. doi:10.1029/98JB00167

Tucholke, B. E., Fujioka, K., Ishihara, T., Hirth, G., and Kinoshita, M., 2001. Submersible study of an oceanic megamullion in the central North Atlantic. Journal of Geophysical Research, 106(16), 145-116. doi:10.1029/2001JB000373

Vitale Brovarone, A., Beltrando, M., Malavieille, J., Giuntoli, F., Tondella, E., Groppo, C., Beyssac, O., Compagnoni, R., 2011. Inherited Ocean - Continent Transition zones in deeply subducted terranes : Insights from Alpine Corsica. LITHOS 124, 273-290.

Vitale Brovarone, A., Beyssac, O., Malavieille, J., Molli, G., Beltrando, M., Compagnoni, R., 2013. Stacking and metamorphism of continuous segments of subducted lithosphere in a highpressure wedge: the example of Alpine Corsica (France). Earth Science Reviews 116, 35-56.

Vitale Brovarone, A., Picatto, M., Beyssac, O., Lagabrielle, Y., Castelli, D., 2014. The blueschisteclogite transition in Alpine orogenic belts: PT paths and the role of slow-spreading extensional structures in the evolution of HP-LT mountain belts. Tectonophysics, 615-616, 96-121.

Weissert, H., Bernoulli, D., 1985. A transform margin in the Mesozoic Tethys: evidence from the Swiss Alps. Geologische Rundschau, 74/3, 665-679.

Zhao, M., Qiu, X., Li, J., Sauter, D., Ruan, A., Chen, J., Cannat, M., Singh, S., Zhang, J., Wu, Z., Niu, X., 2013. Three-dimensional seismic structure of the Dragon Flag oceanic core complex at the ultraslow spreading Southwest Indian Ridge (49 $\left.39^{\prime} \mathrm{E}\right)$. Geochem. Geophys. Geosyst. 14, 4544-4563. doi:10.1002/ggge.20264 


\section{Figure captions}

Fig. 1. Location maps of the studied areas in the Western Alps (A) and in Corsica (B)

Fig. 2. Simplified structural map of the internal Western Alps with the location of the main ophiolitic bodies described in text (in bold italic).

Fig. 3. Geological map of the Queyras-Monviso regions modified after Lagabrielle (1987). Geological cross sections $\mathrm{AB}, \mathrm{CD}$, and $\mathrm{EFG}$ are presented in Fig. 4.

Fig. 4. Simplified geological cross-sections of the Queyras blueschist units modified after Lagabrielle (1987). See location of sections in Fig. 3.

Fig. 5. Geological map of the Pelvas d'Abriès gabbroic massif. See location of map in Fig. 3.

Fig. 6. Two perpendicular geological cross-sections of the Pelvas d'Abriès gabbroic massif.

Fig. 7. General view of the Pelvas d'Abriès gabbroic massif (A), and some details of the main lithologies forming this massif (B and C). A : Photograph taken from the Crête des Lauzes massif. B : View of the typical coarse-grained, locally pegmatitic metagabbro with a well-defined magmatic bedding. C : View of the South Eastern crest of the Pelvas where the ultramafic layers are numerous (white arrows).

Fig. 8. Geological map of the Peyroun, Pic des Lauzes, Crête des Lauzes ophiolitic bodies and surrounding metasediments, modified after Pinet et al. (1989).

Fig. 9. Two perpendicular simplified geological cross-sections of the Peyroun, Pic des Lauzes, Crête des Lauzes ophiolitic bodies. Sections are located in Fig. 8.

Fig. 10. General view of the Peyroun, Pic des Lauzes and Taillante massifs, looking to the South (A), and its simplified geological interpretation (B).

Fig. 11. Some typical aspects of the Peyroun-Taillante ophiolitic complex. A : General view of the Crête des Lauzes ultramafic body and its metavolcanic-metasedimentary cover (Taillante metabasalts and metasediments) (photograph taken from the north). B : View of well-preserved metapillow-lavas forming the western flank of the Pic des Lauzes body. C and D : Photographs (width is $\sim 50 \mathrm{~cm}$ ) of metadoleritic dikes cross-cutting the typical coarse-grained, bedded, metagabbros at the Roche Ecroulée site, Pic des Lauzes body (see description in text and location in Figs. 8, 9 and 12)

Fig. 12. Schematic lithostratigraphic sections around the Pelvas d'Abriès gabbroic massif (see location of sections in Fig. 5).

Fig. 13. Field photographs illustrating the stratigraphic relationships between the ophiolitic basement and the metasediments in the Pelvas d'Abriès massif (see location of photographs in Fig. 12). A and B : marbles underlying metagabbros in the overturned section of Cold d'Urine. In A, note that the base of the metasediments is oblique to the magmatic layering of the gabbros, and that a fissure opened within the gabbros has been filled by sediments. In B, small gabbroic clasts are found within the metasediments, thus confirming a primary stratigraphic relationship. C and D : marbles overlying ophilcalcites in the Sagnes Clauses section.

Fig. 14. Simplified geological cross-section of the Crête des Lauzes-Taillante massif and corresponding reconstructed stratigraphic log based on lithostratigraphic successions a-b and $c-d$. The cross-section is build from projecting three geological sections on a single surface containing the Crête des Lauzes body.

Fig. 15. The Rocca Bianca-Farneireta ophiolitic body. A : Simplified geological map modified from Tricart et al. (2003). B and C : Geological cross-sections a-b and c-d located in A. D : A possible reconstruction of the oceanic basement and its first sedimentary cover involving a detachment fault 
capping the gabbros. This reconstruction refers to recent discoveries at modern slow-spreading ridges, and is modified according to the structure of modern OCCs after an original cartoon by Lagabrielle (1982) (unpublished thesis).

Fig. 16. Field photographs illustrating the main geological features observed in the Rocca Bianca ophiolitic body. A and B : General view of the massif, looking toward the East, showing the stratigraphic relationships between the ophiolitic basement and the metasediments (marbles and calcschists). C and D : Detailed view of the stratigraphic contact between mafic metabreccias and the marbles.

Fig. 17. Blueschist-facies metaophiolites in the Golo valley (Alpine Corsica). A: simplified geological map of the study area. B : geological projection of the Bigorno Pass area showing the relations between serpentinites, carbonated ultramafics, metasediments and gabbro metabreccias. $\mathrm{C}$ : Example of rocks interpreted as carbonated peridotites (Bigorno Pass). D : Microgabbro metabreccia at Bigorno Pass. E: photomicrograph of a blueschist-facies metagabbro from the Golo valley showing the occurrence of pre-Alpine HT, kaersutitic amphibole overgrown by Alpine green amphibole. F : thick pillow metabasalt sequence in the Saliceto area. See also Vitale Brovarone et al. (2014) for details.

Fig. 18. A reconstruction of the Tethyan oceanic basement based on the variety of lithostratigraphic successions observed in Alpine and Corsican metaophiolites. Typical sections observed in the field are shown by arrows (1 to 5) in the Queyras blueschist units (A) and in the Corsica blueschist units (B). Basement rocks may include ultramafic rocks and gabbros. Cover successions may include ophiolitic breccias, volcanic products or pelagic sediments. The successions 1 to 5 are then replaced on a schematic section of a modern OCC (C). The reference model is taken from the example of the wellknown eastern intersection of the MAR with the Kane fracture zone (MARK area) (Juteau et al., 1990a, 1990b; Mével et al., 1991; Cannat et al., 1995a; Karson et al., 1997a, 1997b) (see fig. 19 for more details).

Fig. 19. Geological map and cross-section of the MARK area (Mid Atlantic Ridge at Kane intersection, Central Atlantic) to illustrate the presence of exhumed gabbros and ultramafic rocks along slow-spreading ridge axis. Despite a considerable amount of more precise data accumulated since the years 1990 along the MAR, and in particular the spectacular 3D view of OCCs and corrugated surfaces, this example remains emblematic for all comparisons between Alpine-type ophiolites and slow-spreading centers (redrawn and modified after Mével et al., 1991 and Karson et al. 1997a, 1997b).

Fig. 20. Reconstruction of the Tethyan oceanic basement involving exhumation of deep rocks along two detachment faults with similar orientation (A). One detachment leads to a mantle-hosted OCC (left), the other one to a gabbro-hosted OCC (right). Such geometry is based on the geology of the Rocca Bianca-Farneireta ophiolitic massif. Comparable axial topographies may result of faulting along detachment faults with similar (B1) or opposite (B2) verging. The geometry resulting from a succession of mantle-hosted OCC is closer to the structures described along ultra-slow spreading ridges with very low magma budget (smooth sea-floor).

Fig. 21. Simplified reconstruction of the Tethyan oceanic basement from the geology of two ophiolitic massifs of the South Western Alps (Queyras blueschists units) : the Cascavelier and Roche Noire bodies (see location in Fig. 2).

Fig. 22. Cartoons depicting a 3-steps evolution of the Tethyan oceanic basement using the model of OCC development. 


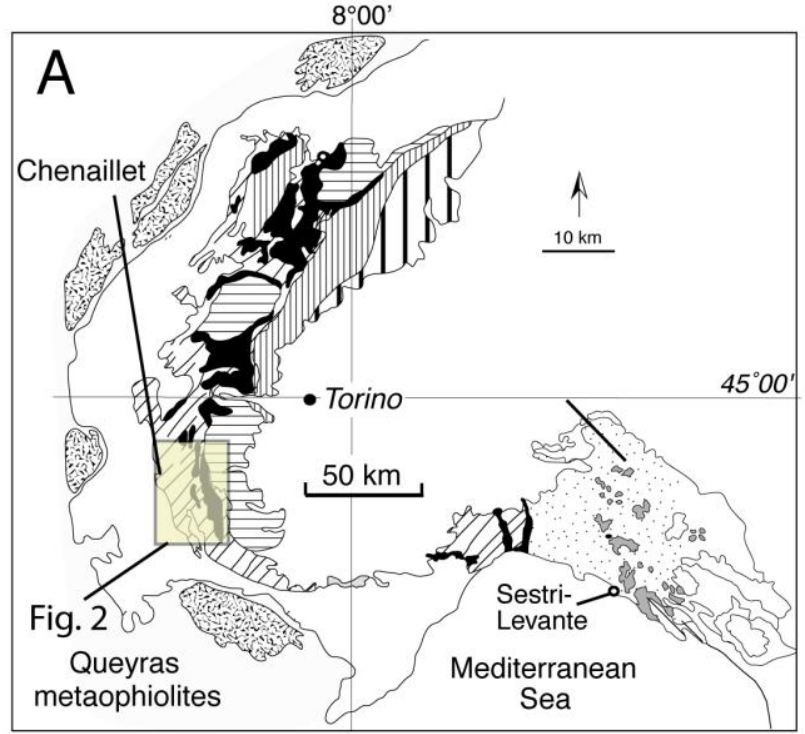

WESTERN ALPS \& LIGURIA

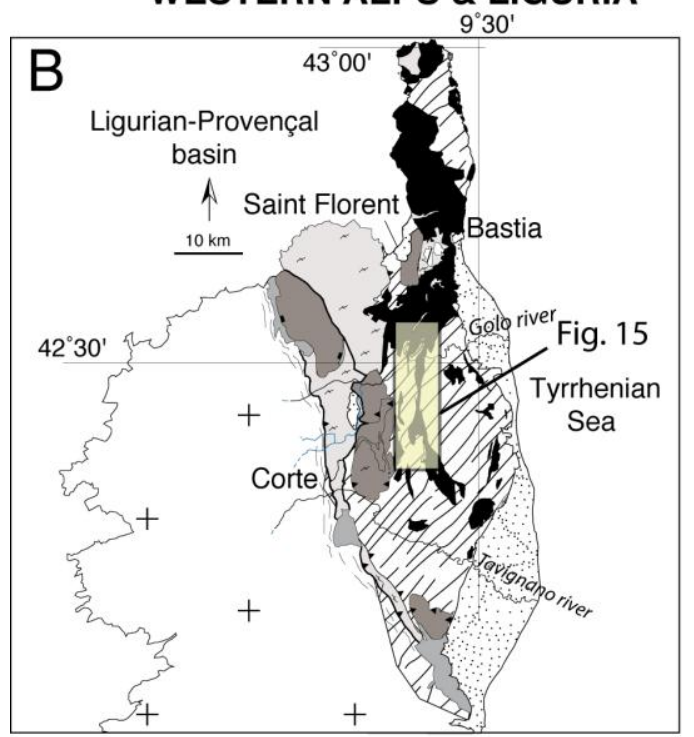

ALPINE CORSICA

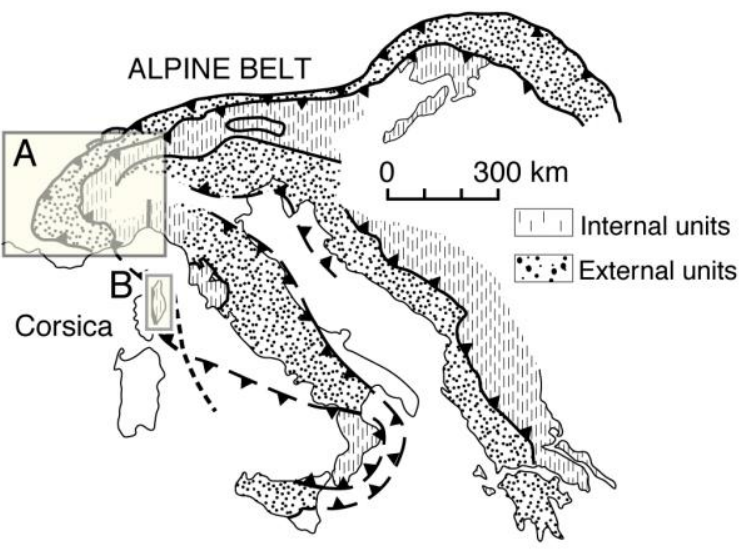

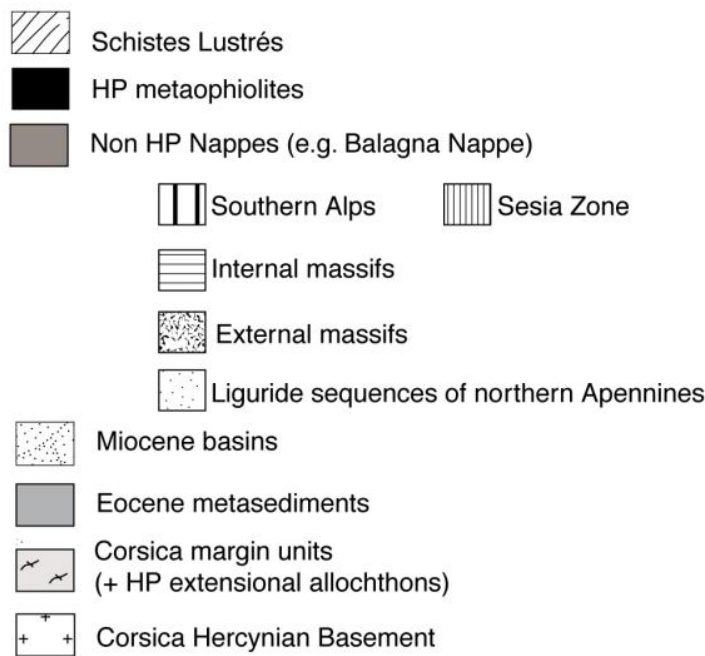

Lagabrielle et al., fig. 1 


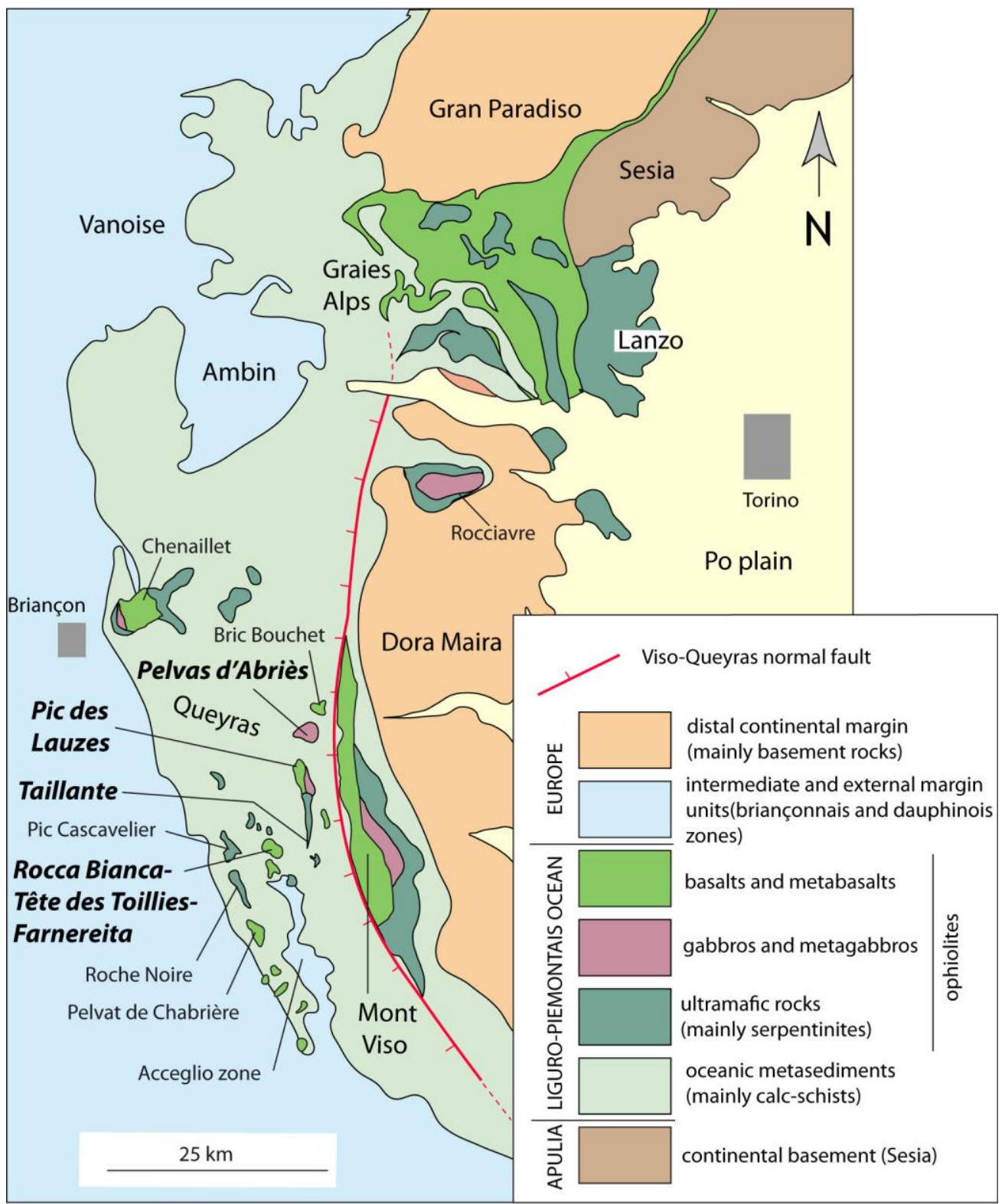

Lagabrielle et al. fig. 2 


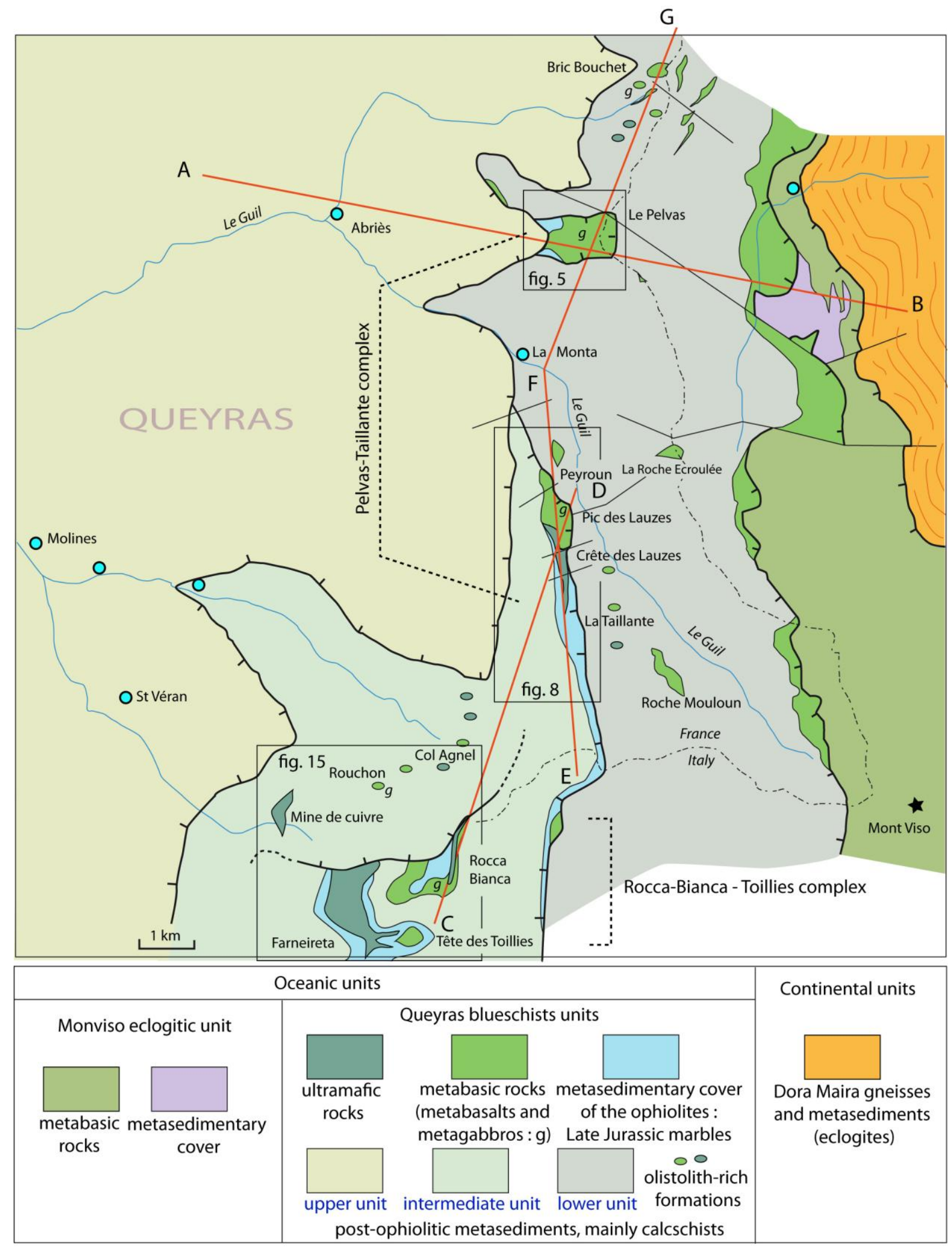

Lagabrielle et al., fig. 3 
W

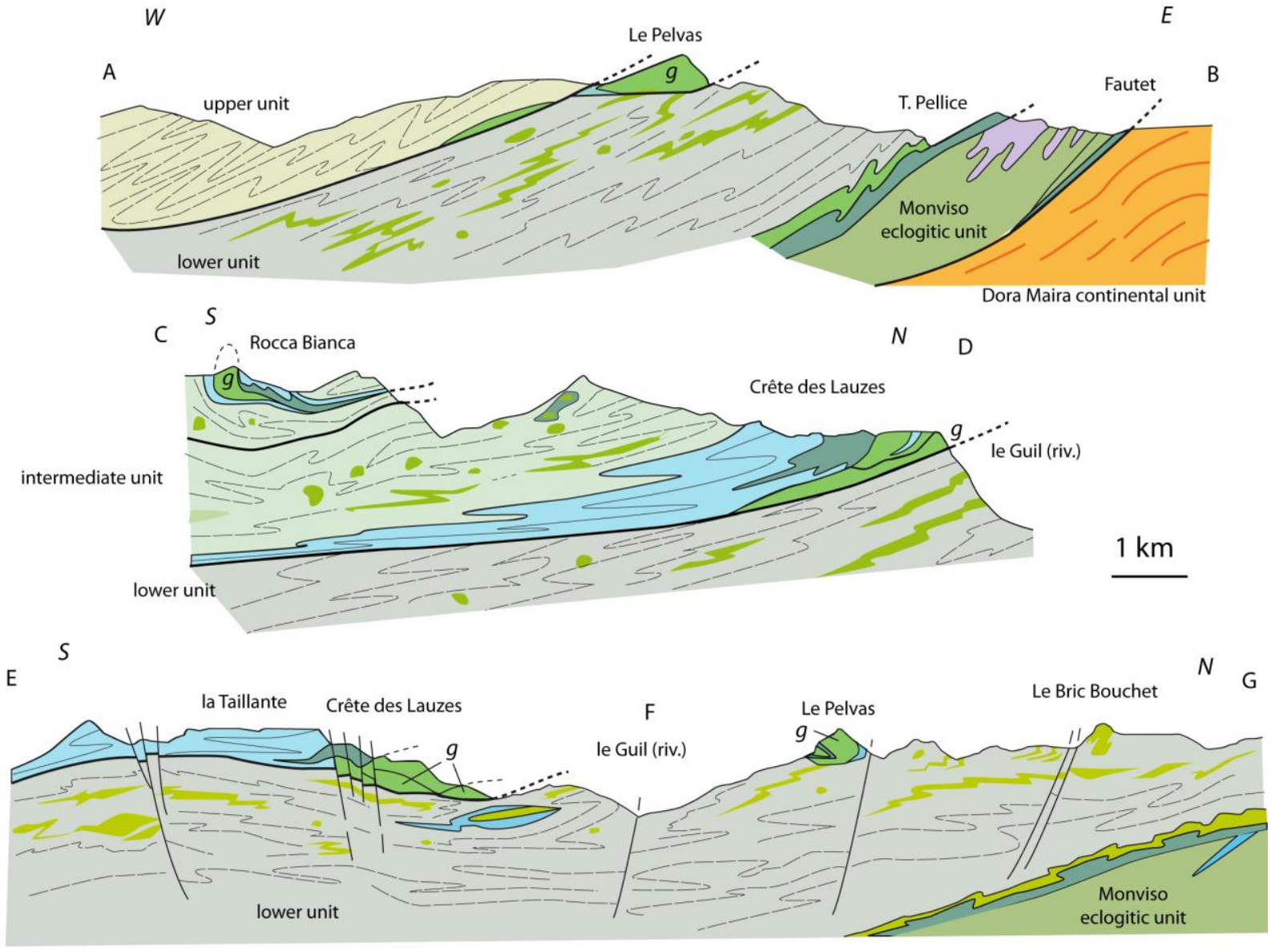

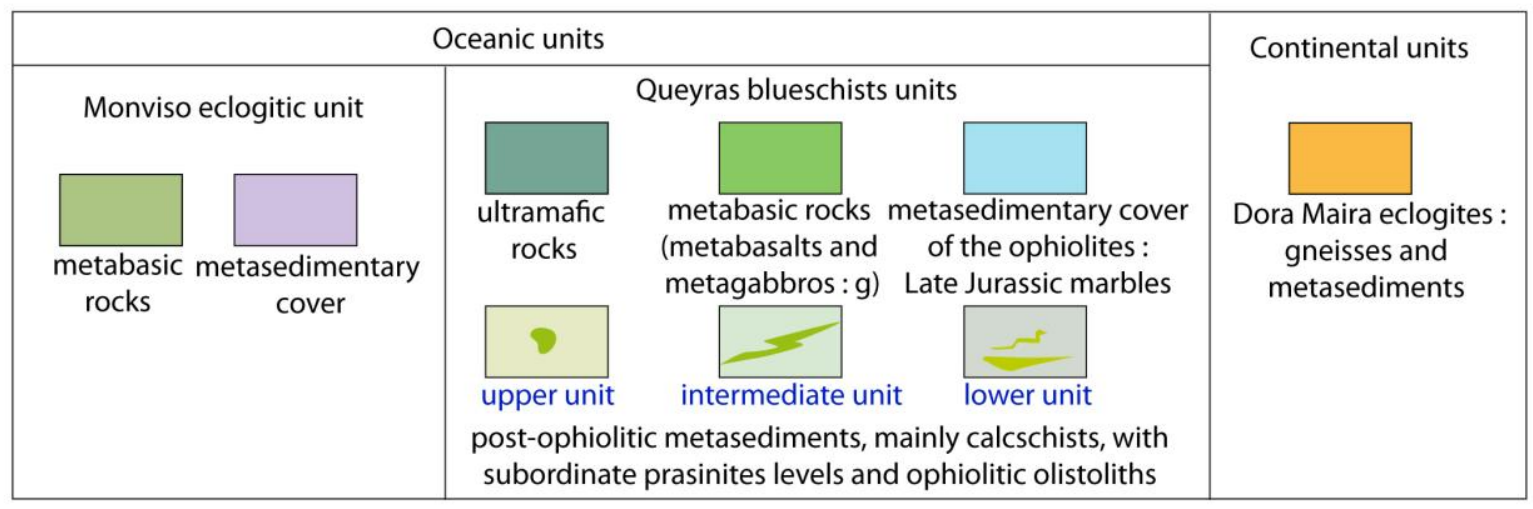

Lagabrielle et al. fig.4 


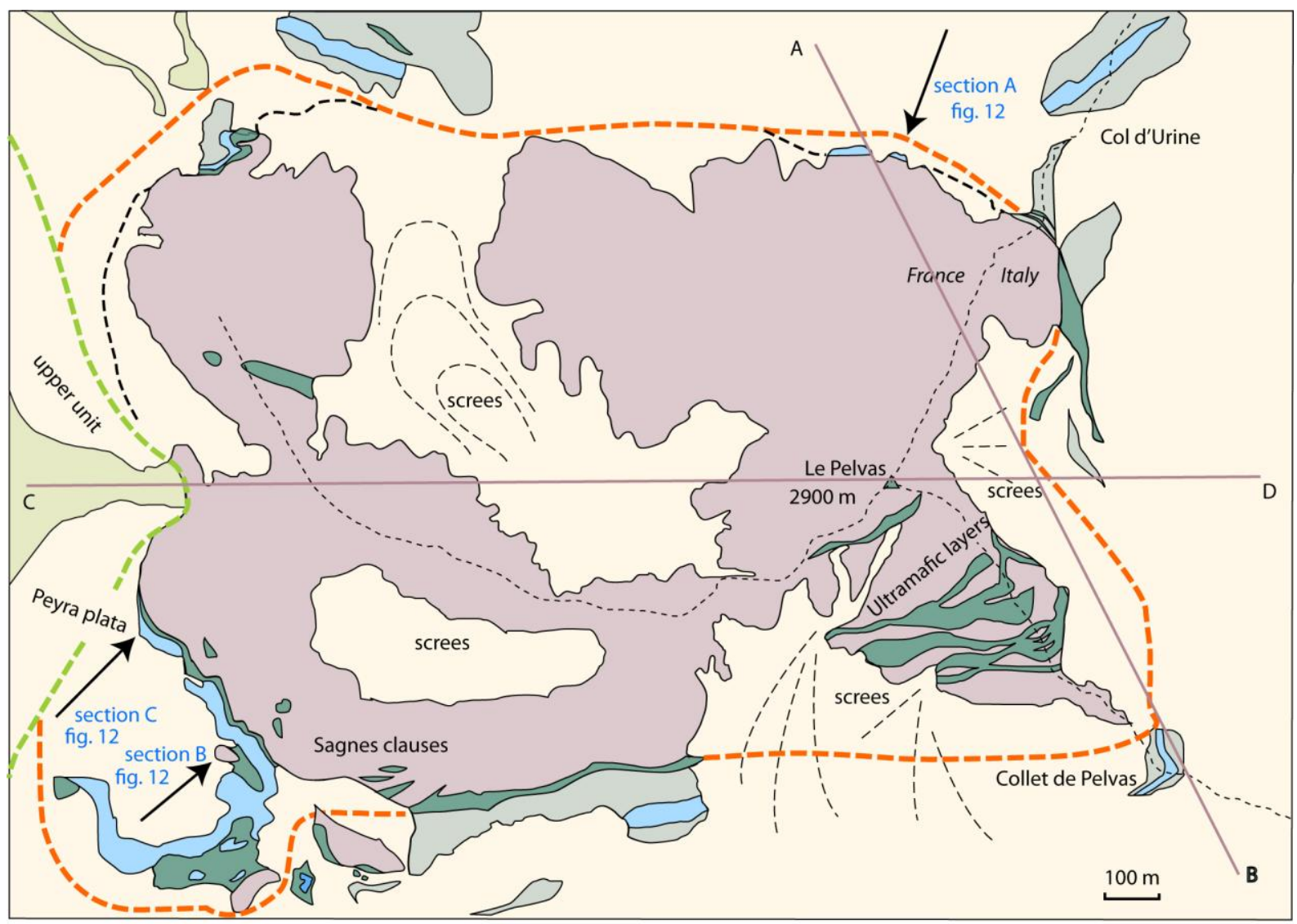

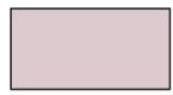

gabbros and ferro-gabbros serpentinites
(ultramafic layers in gabbros and mantle-derived metabreccias)

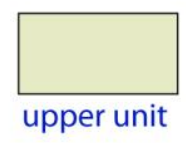

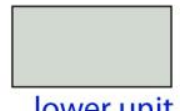

lower unit

calcschists and subordinate lithologies

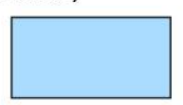

marbles
- - - basal contact of the Pelvas klippe basal contact of the blueschist upper unit ---- basal limit of the gabbro body (prasinites, quartzites, phyllitic marbles)

\section{Lagabrielle et al. fig. 5}




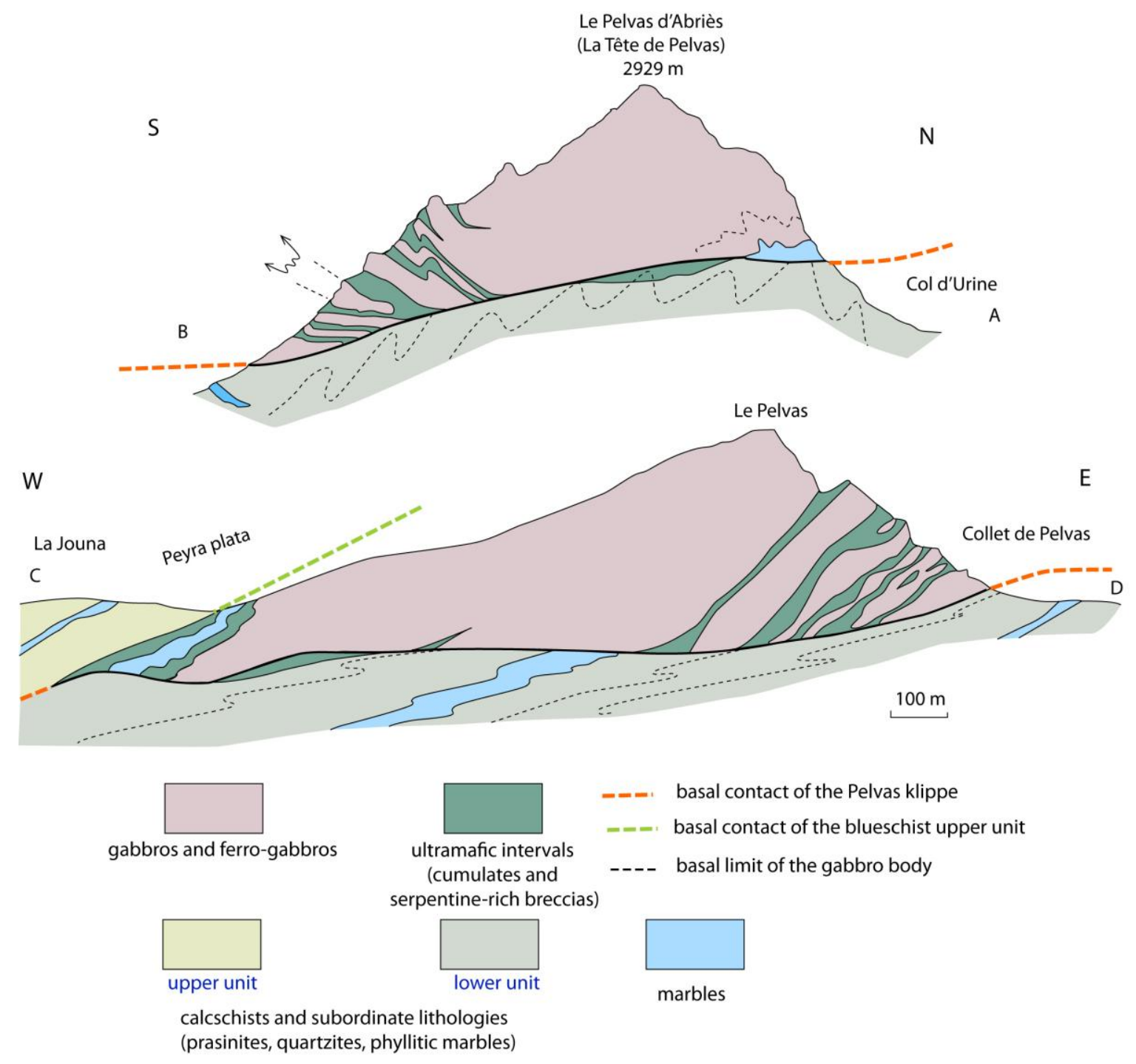

Lagabrielle et al. Fig. 6 

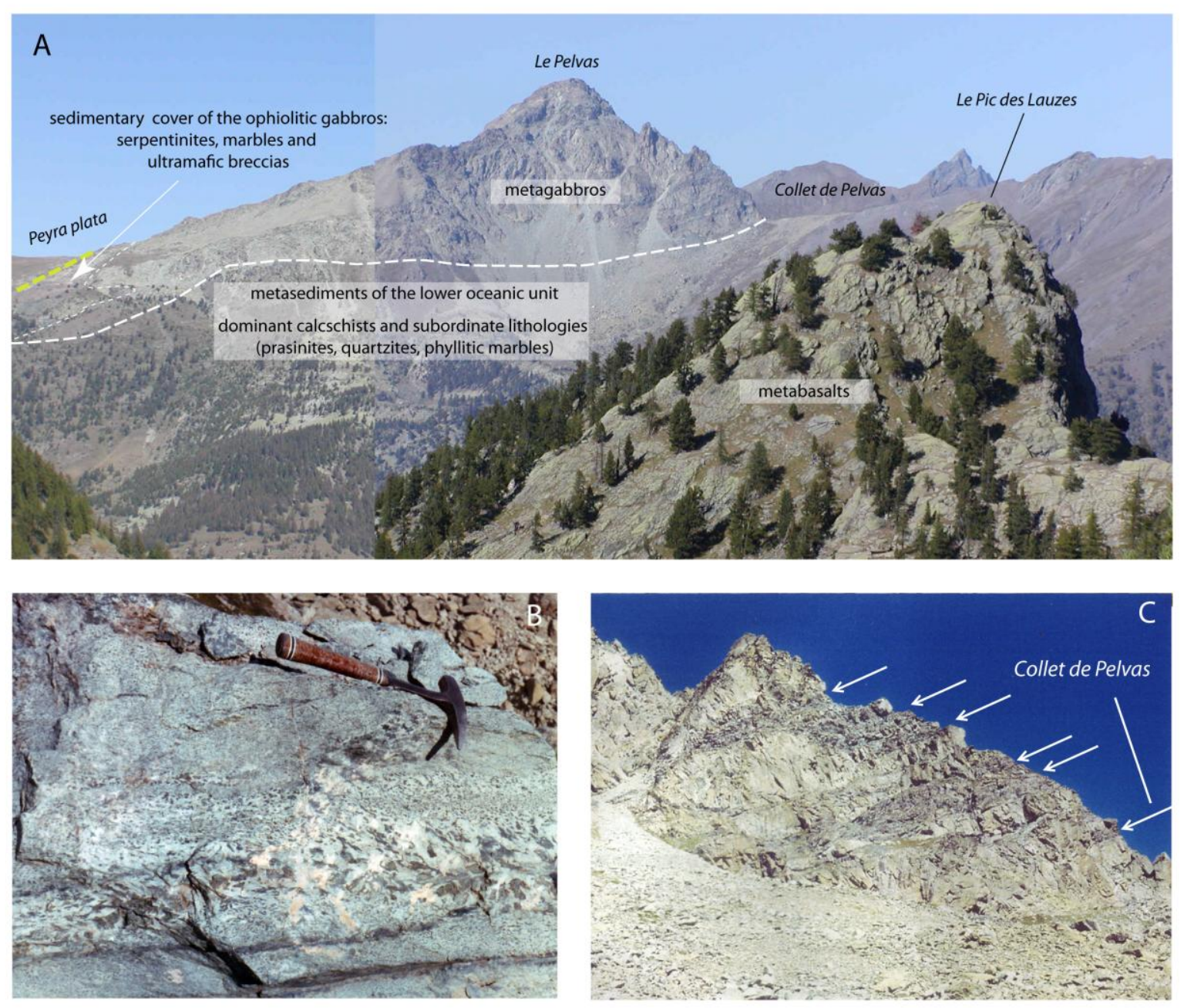

Lagabrielle et al. fig. 7 


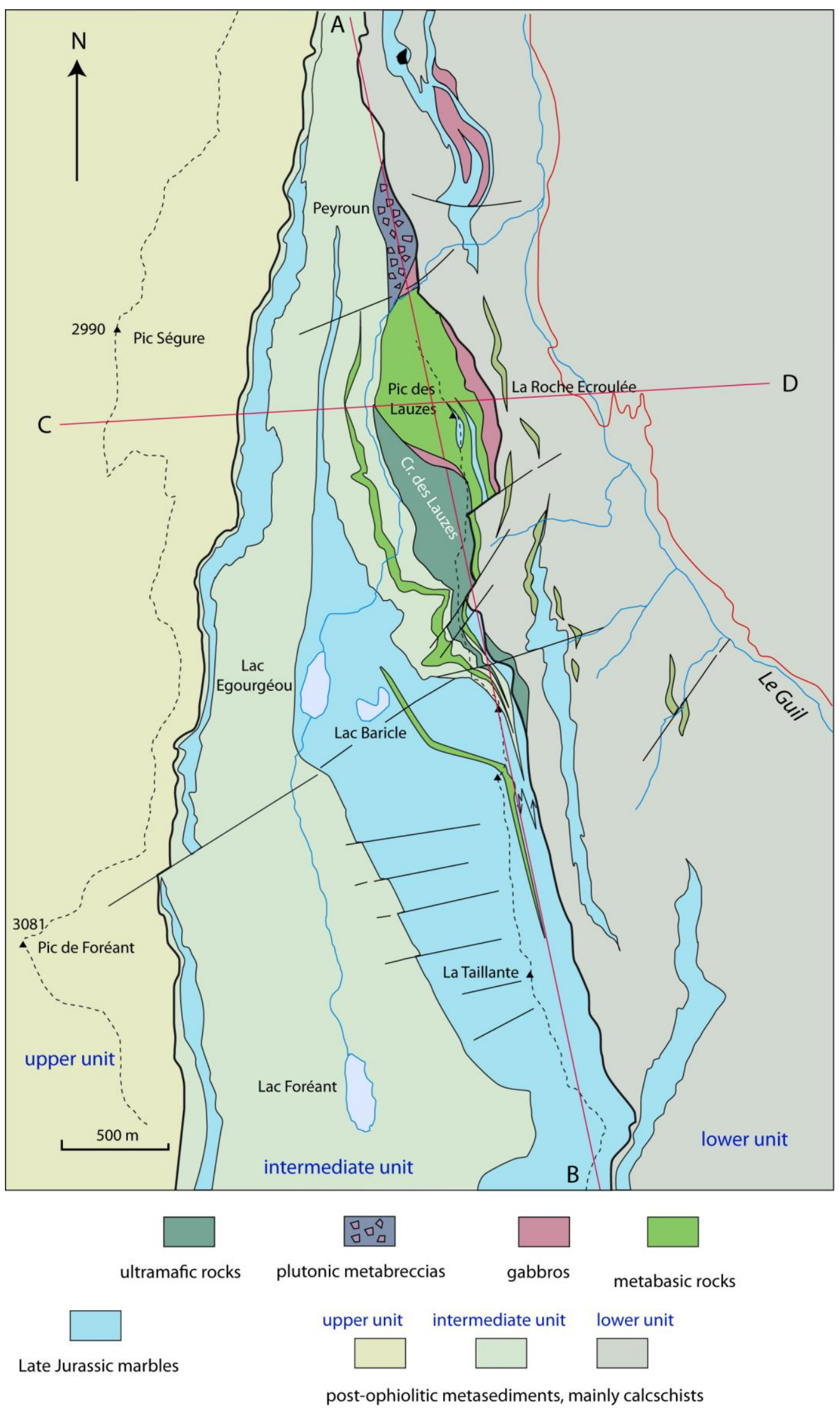

Lagabrielle et al. fig. 8 


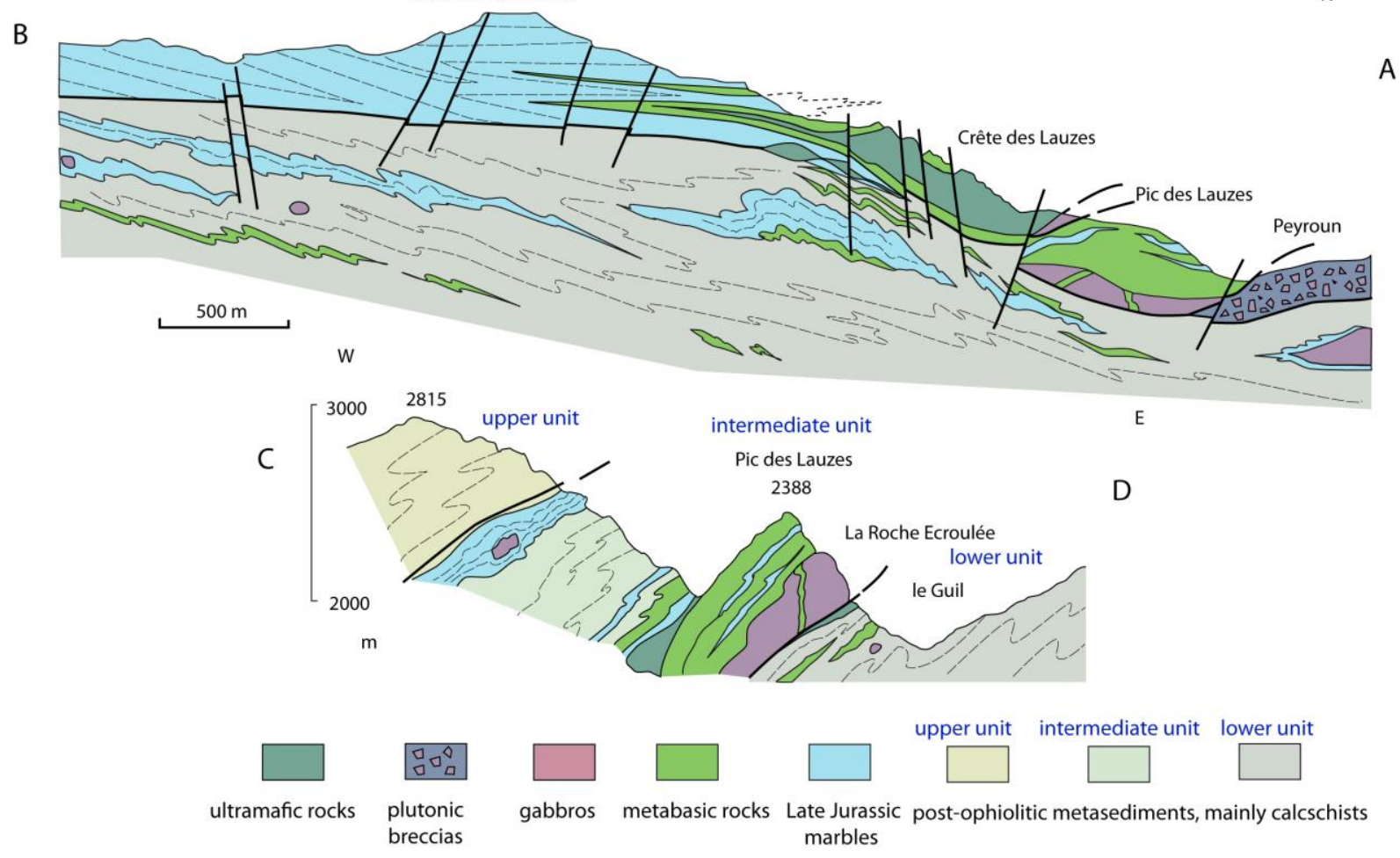

Lagabrielle et al., fig. 9 

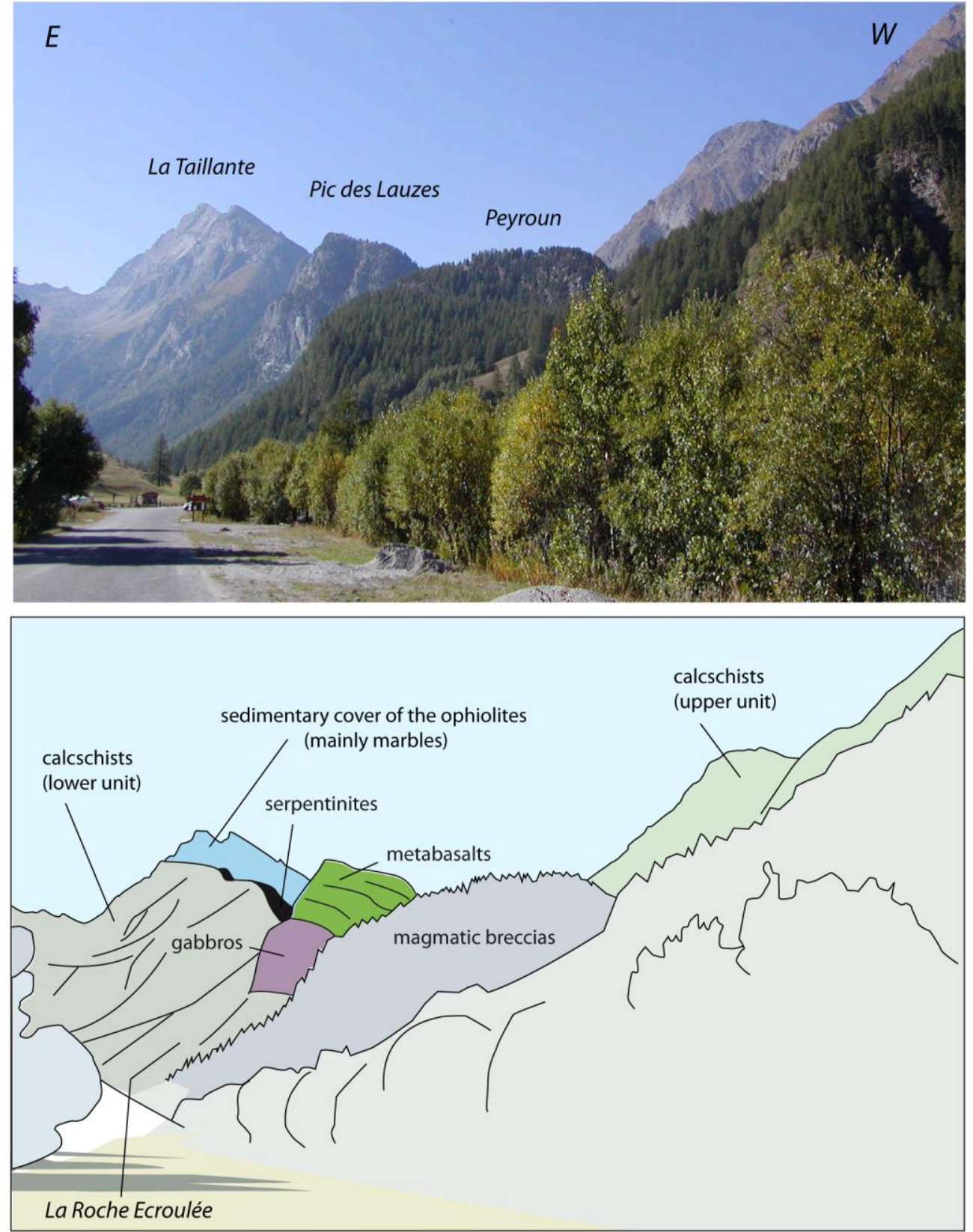

Lagabrielle et al. fig. 10 

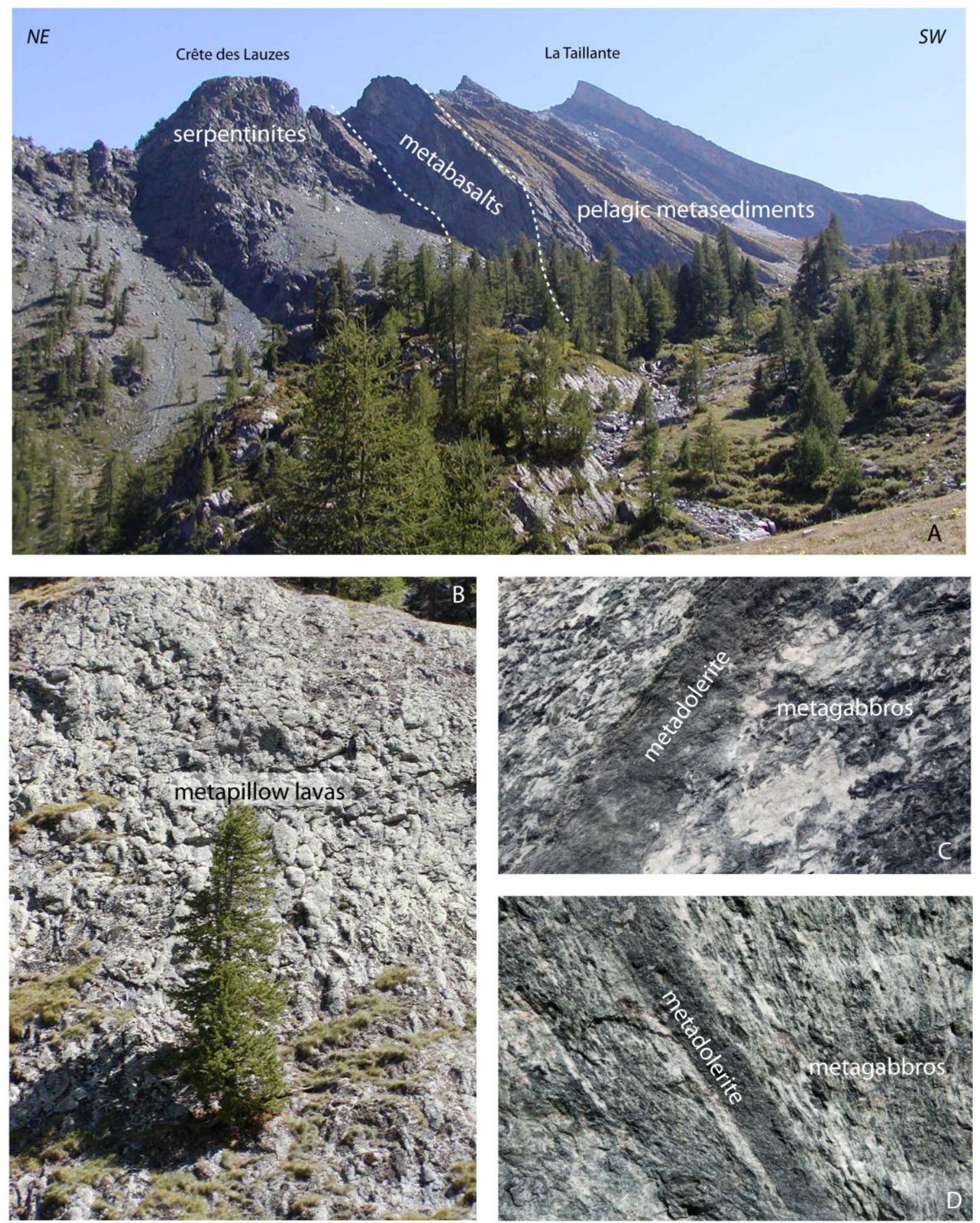

Lagabrielle et al. fig. 11 


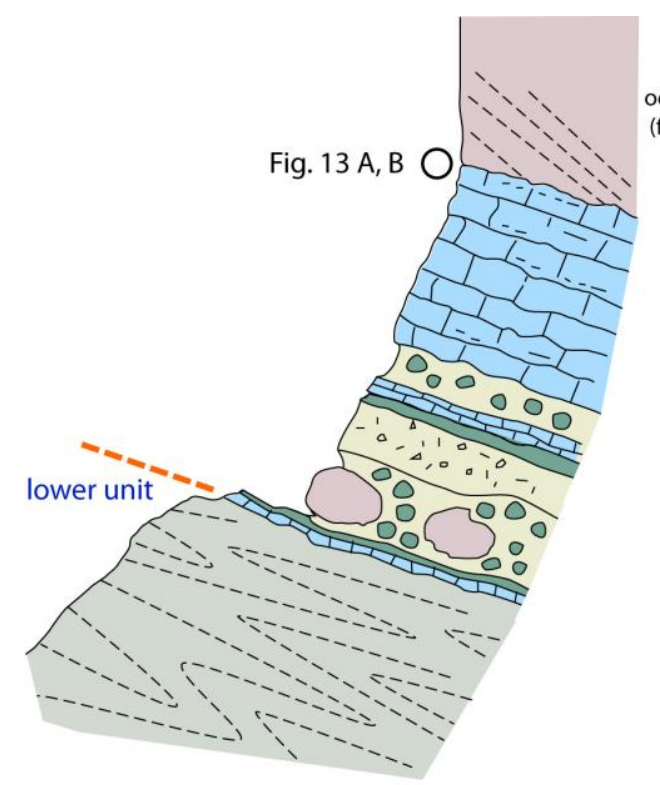

oceanic foliation

(flaser gabbros)

A. Col d'Urine section

$1 \mathrm{~m}$

basal contact of the Pelvas klippe

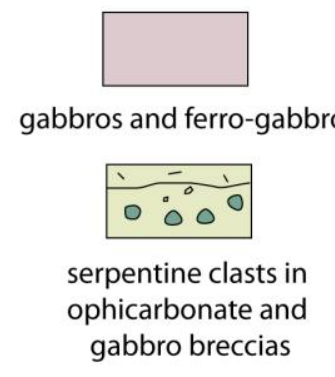

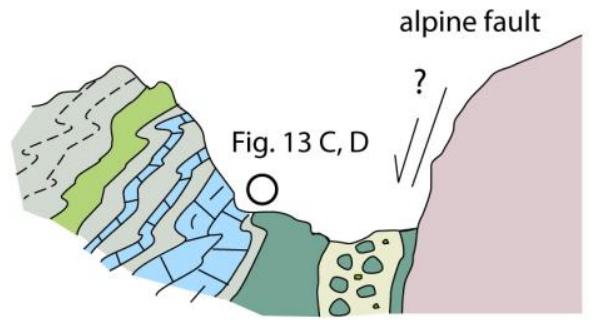

B. Sagnes Clauses section

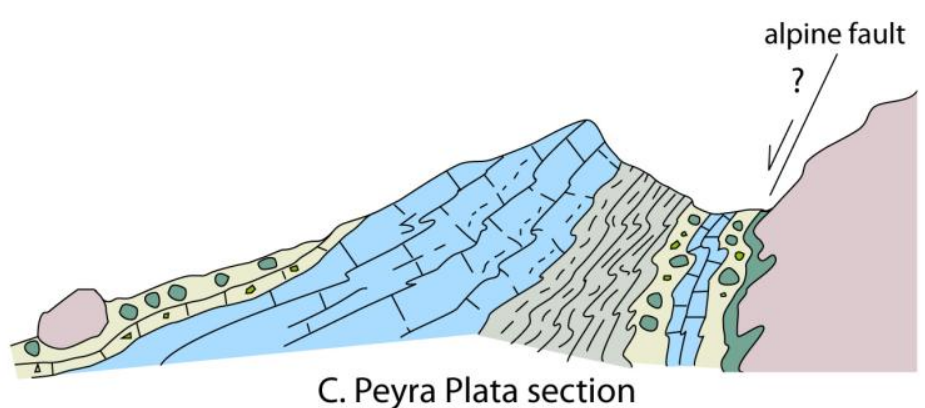

C. Peyra Plata section

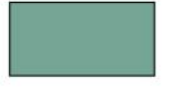

ultramafic breccias

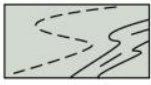

calcschists

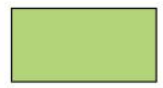

prasinites (basalt meta-breccia)

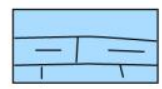

marbles and phyllitic marbles

Lagabrielle et al. fig. 12 

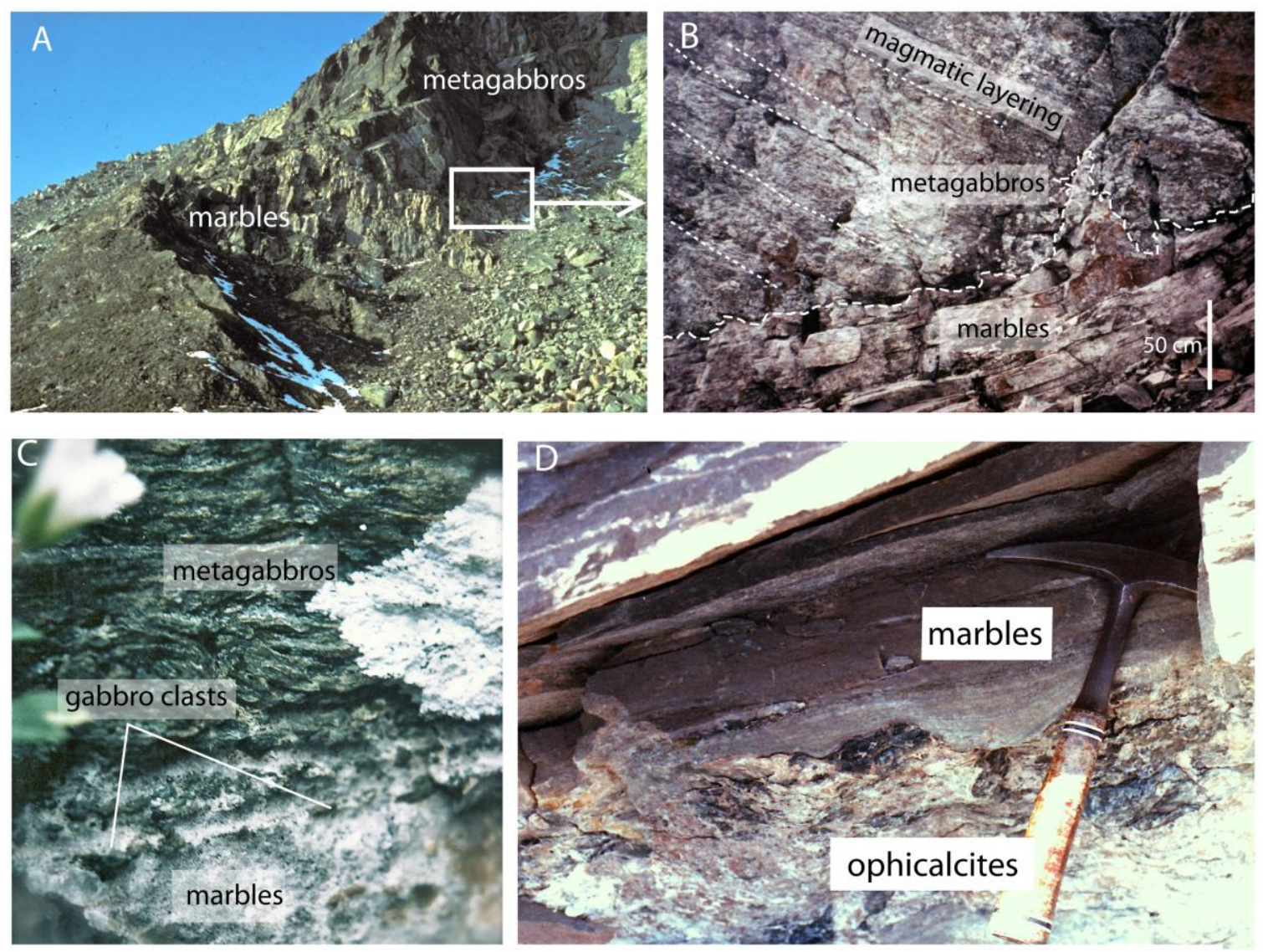

Lagabrielle et al. fig. 13 

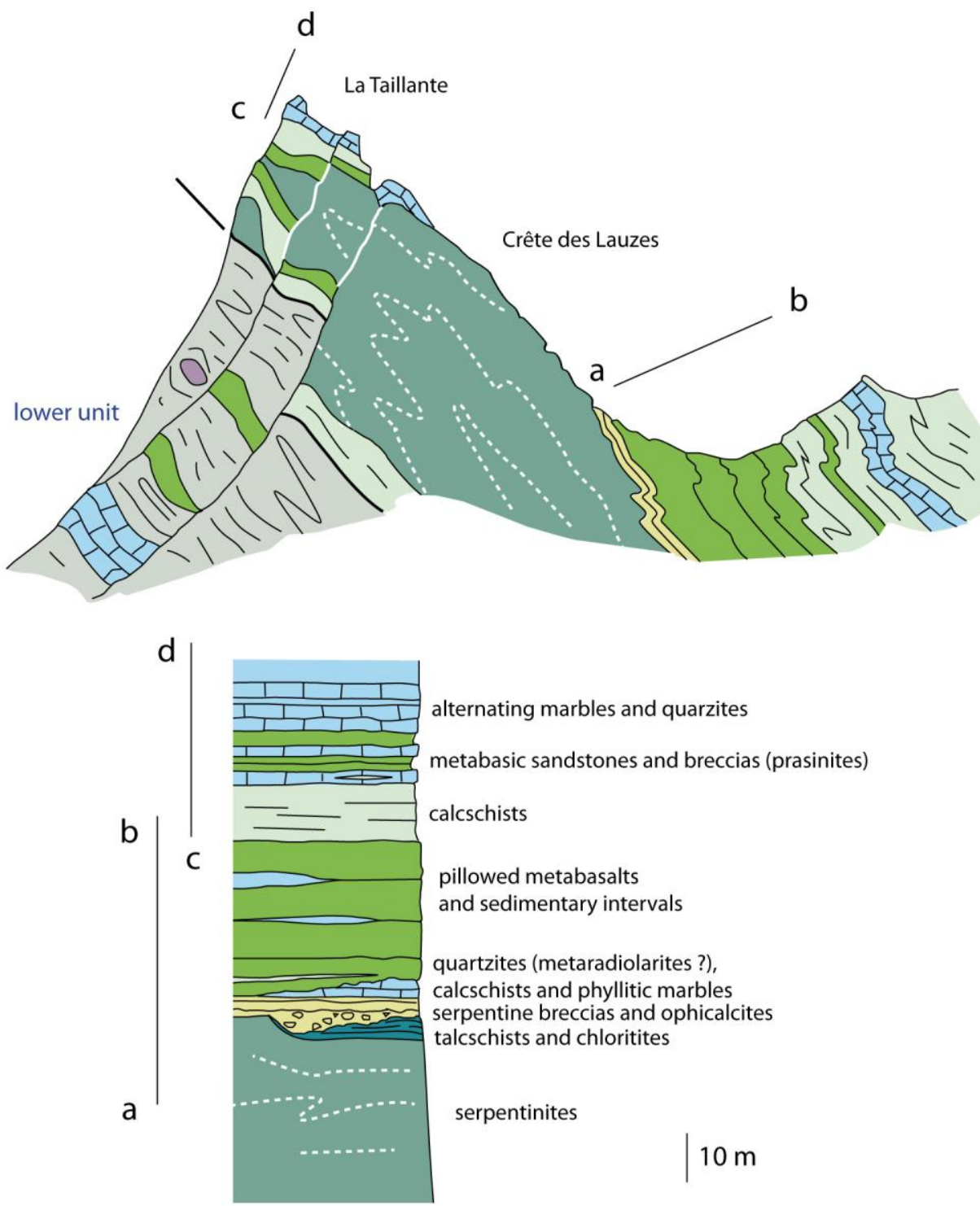

Lagabrielle et al fig. 14 


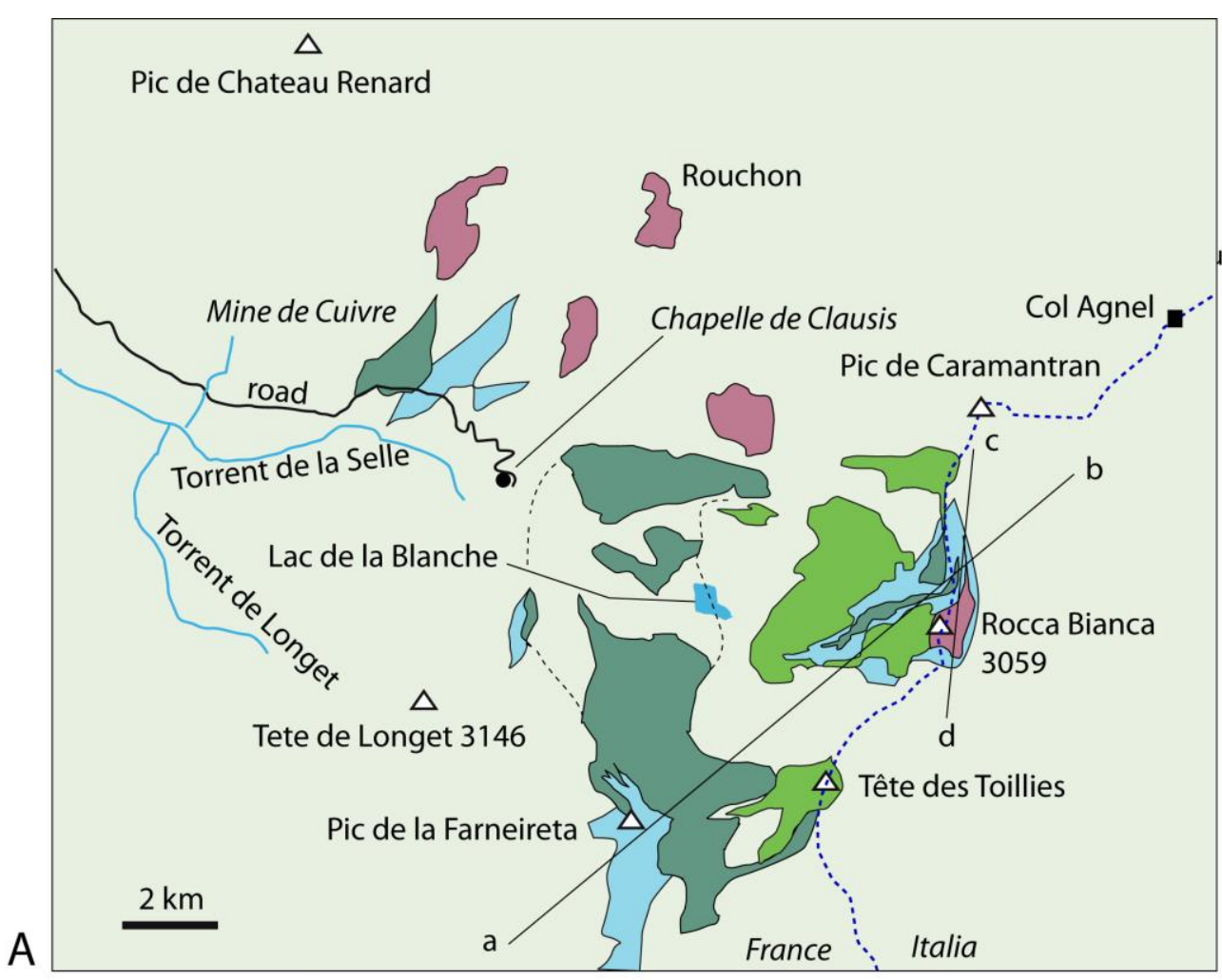

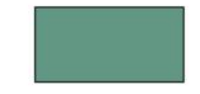

serpentinites and Itramafic metabreccias

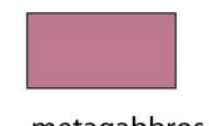

metagabbros

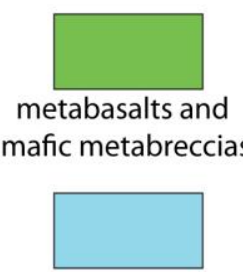

Jurassic marbles and radiolarites

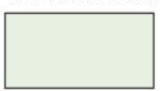

calcschists and Quaternary deposits

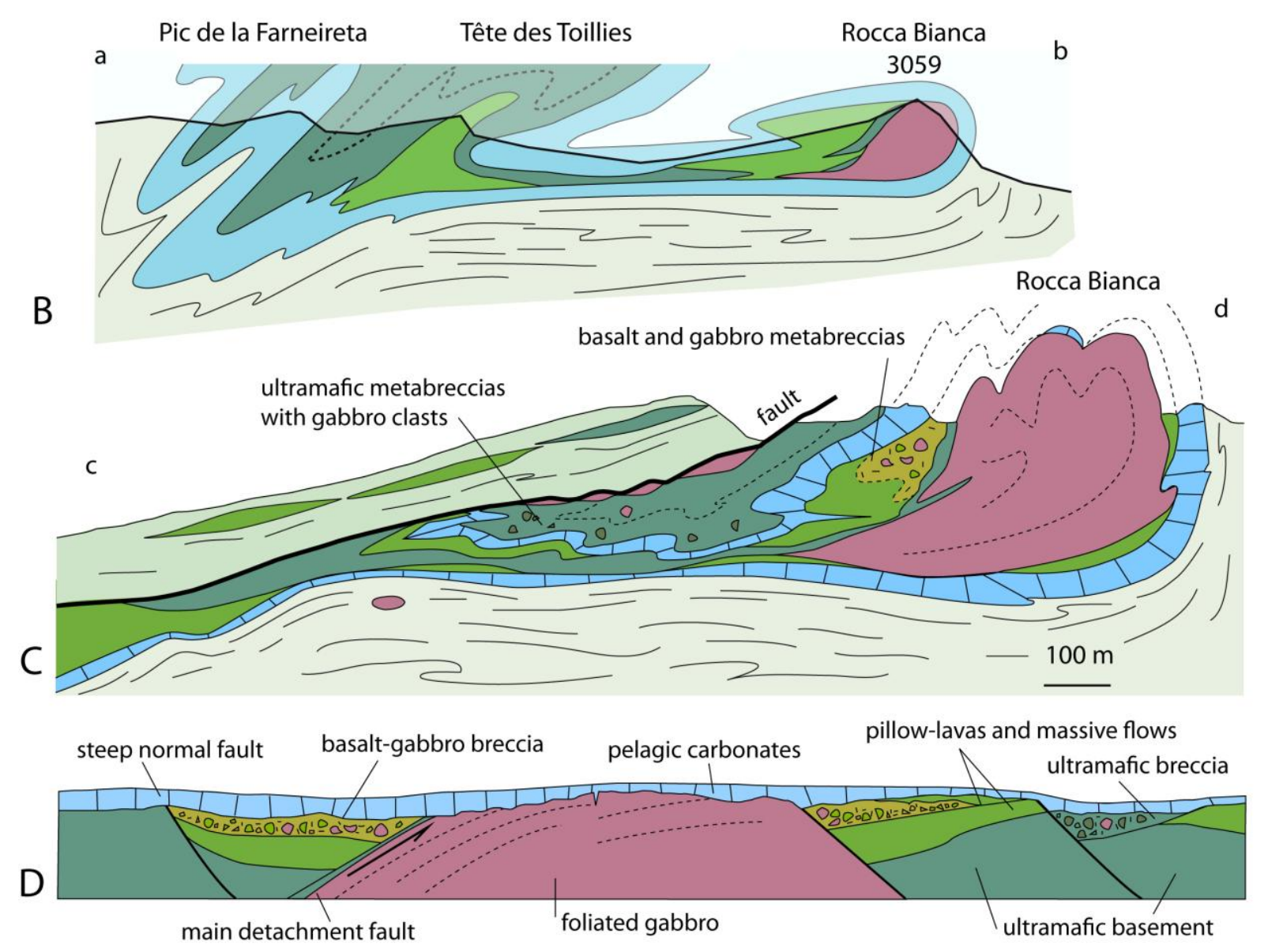

Lagabrielle-etal. Fig. 15 

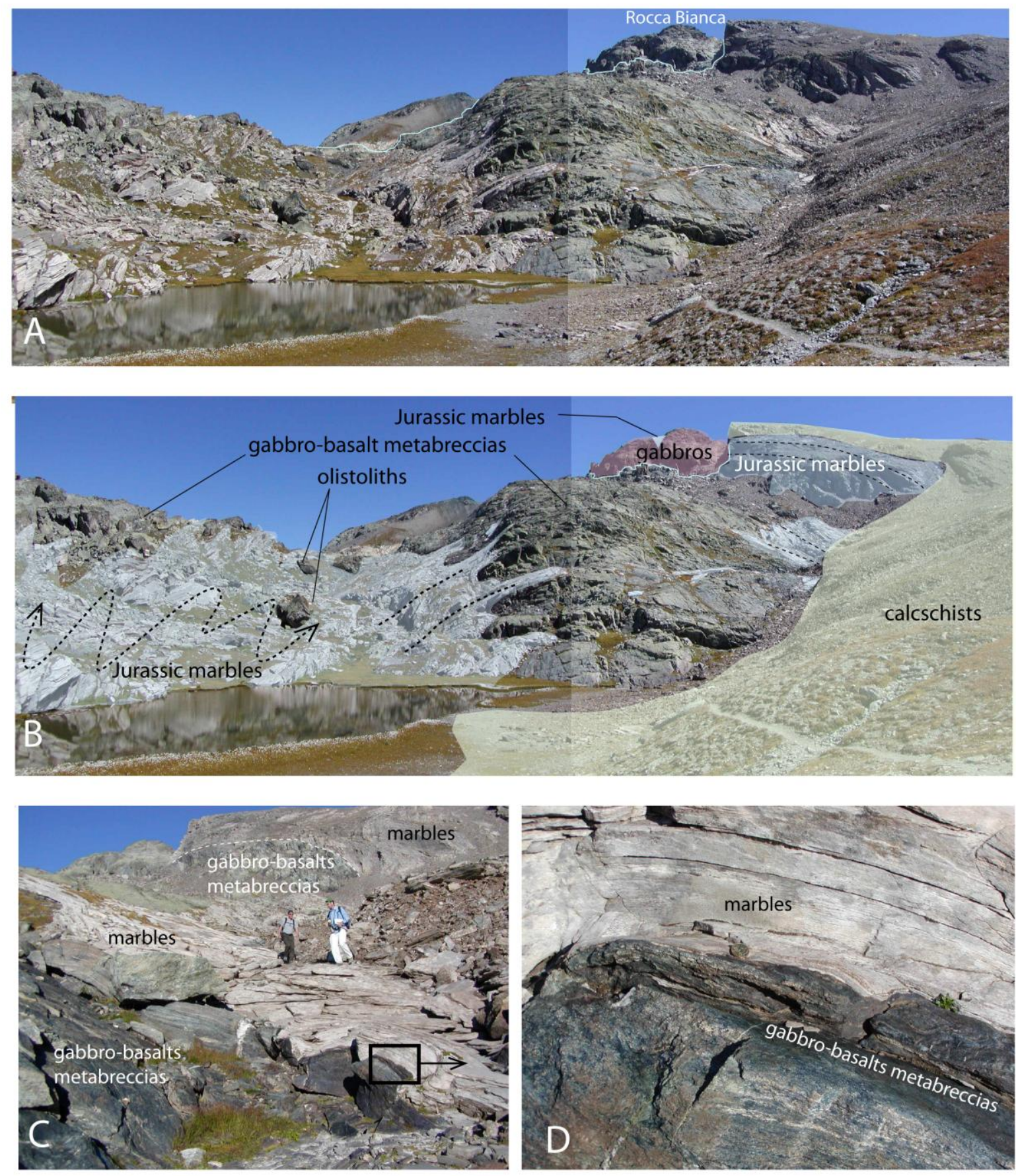

Lagabrielle et al. fig. 16 


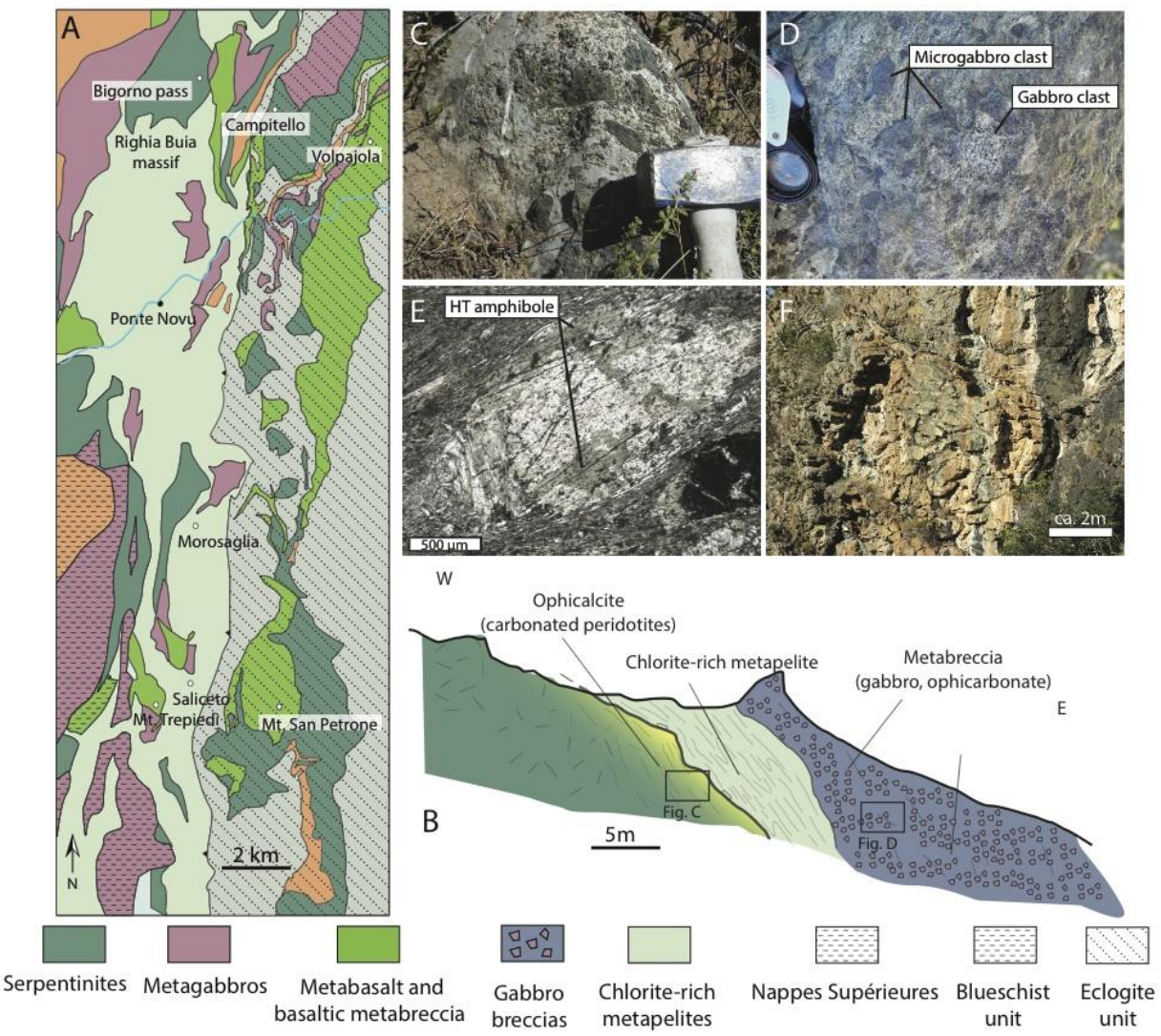

Figure 17 


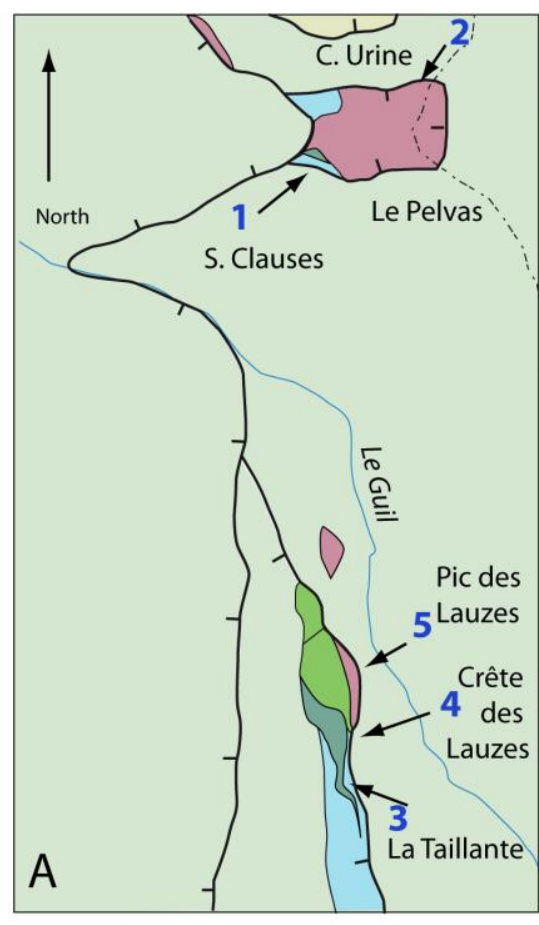

Queyras blueschists units

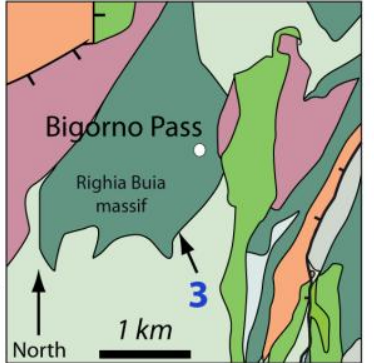

B

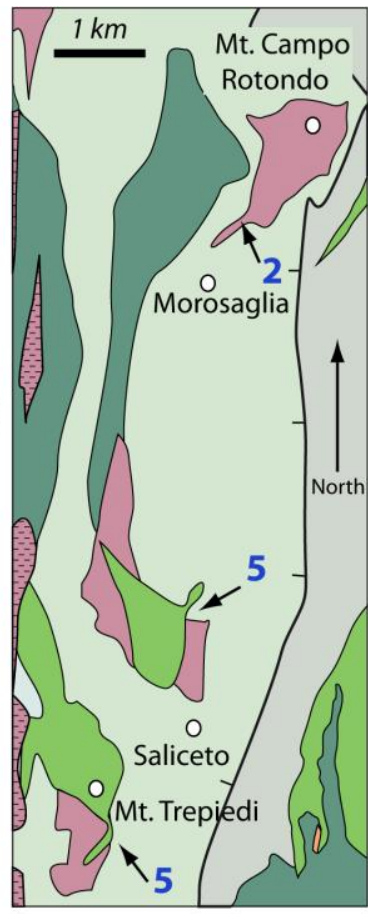

Corsica blueschists units

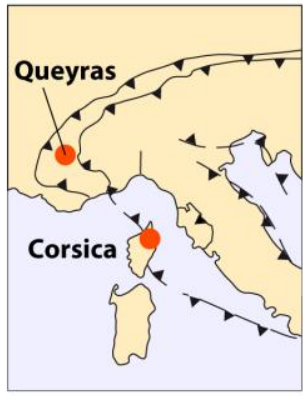

\section{(Corsica only) \\ Supérie}

ultramafic rocks gabbros metabasic rocks Late Jurassic marbles blueschist-facies eclogite-facies metasediments metasediments continental baseent rocks

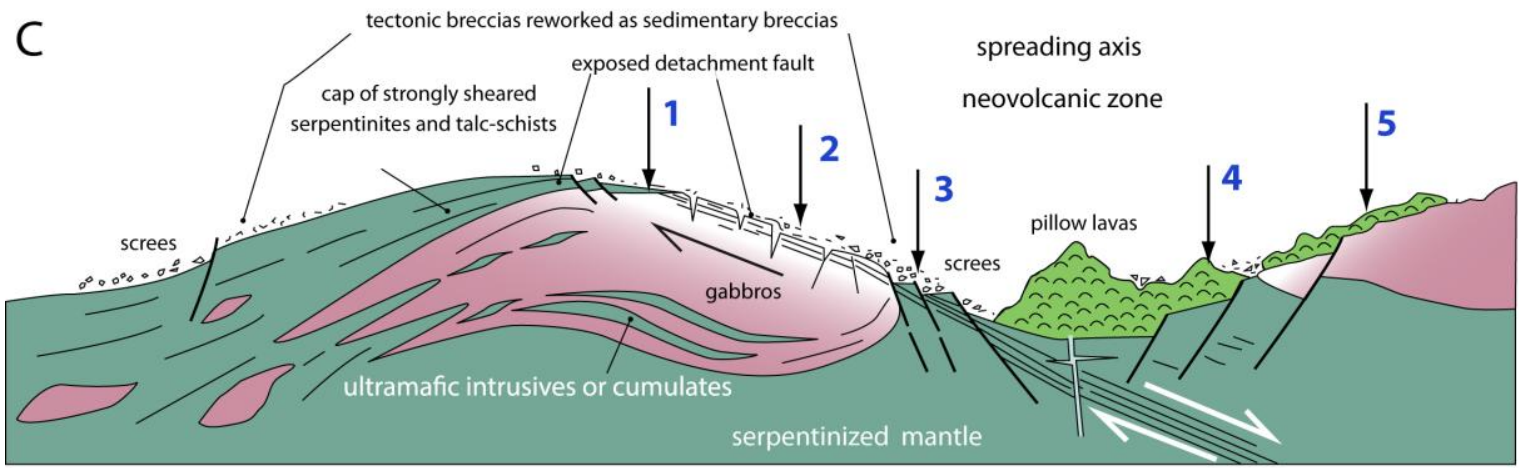

detachment-inherited tectonicfabric 


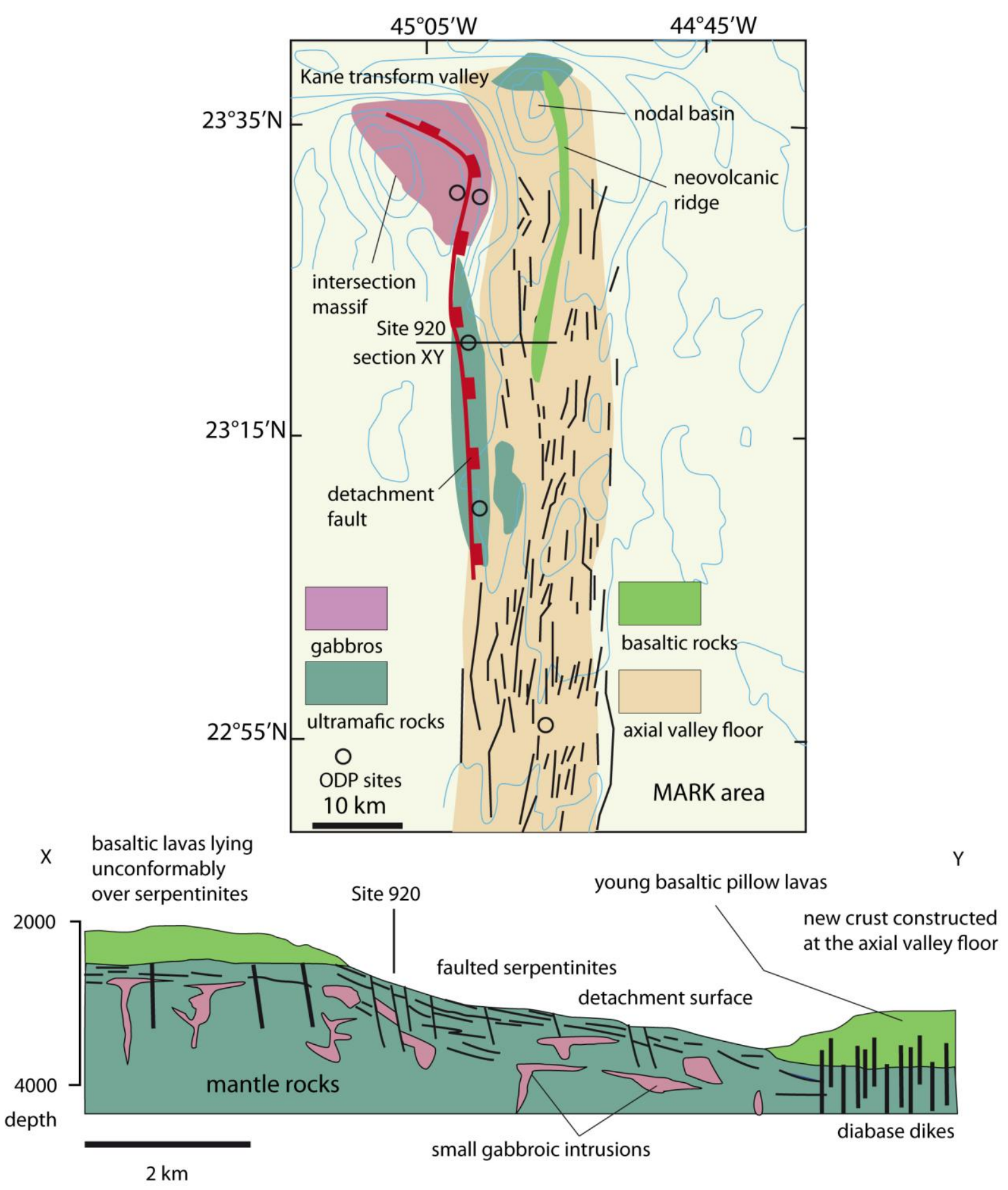

Lagabrielle et al., Fig. 19 

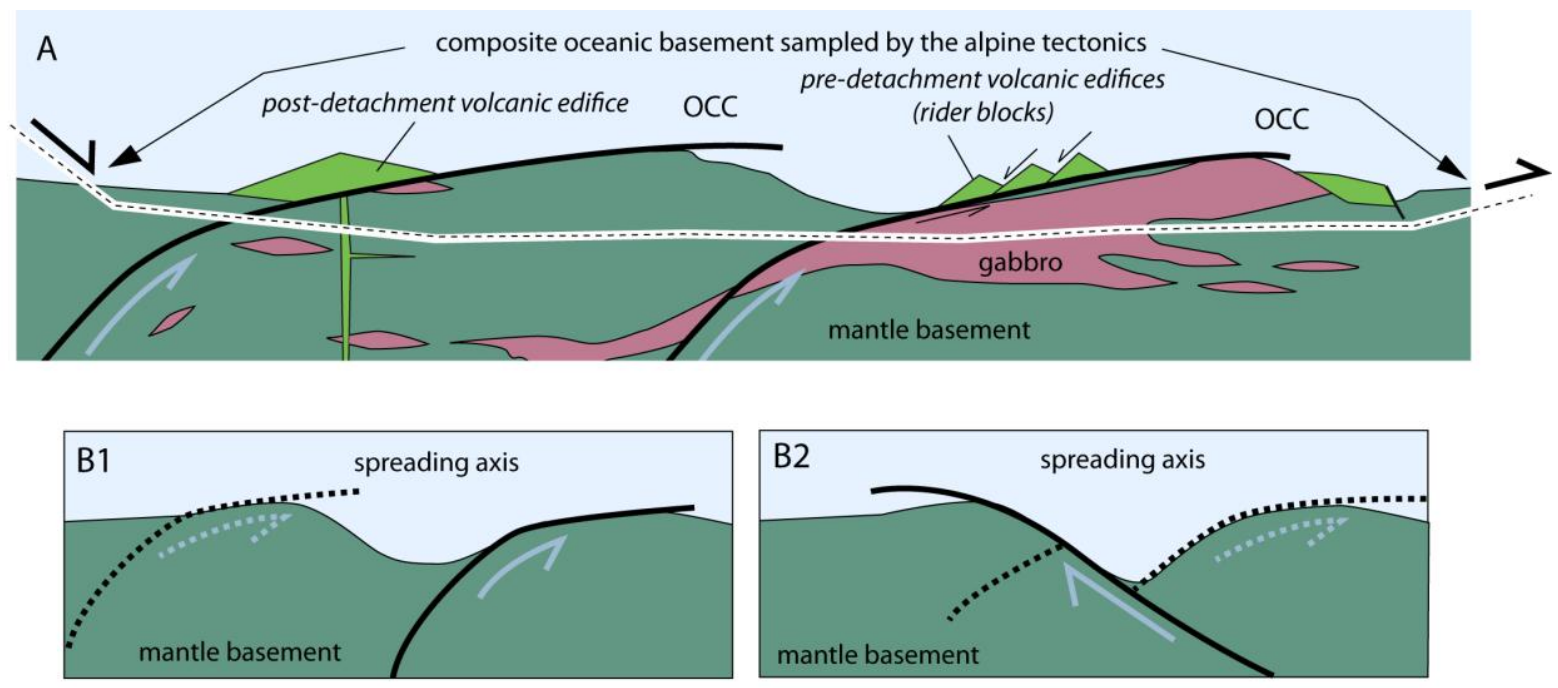

Lagabrielle et al. Fig. 20 


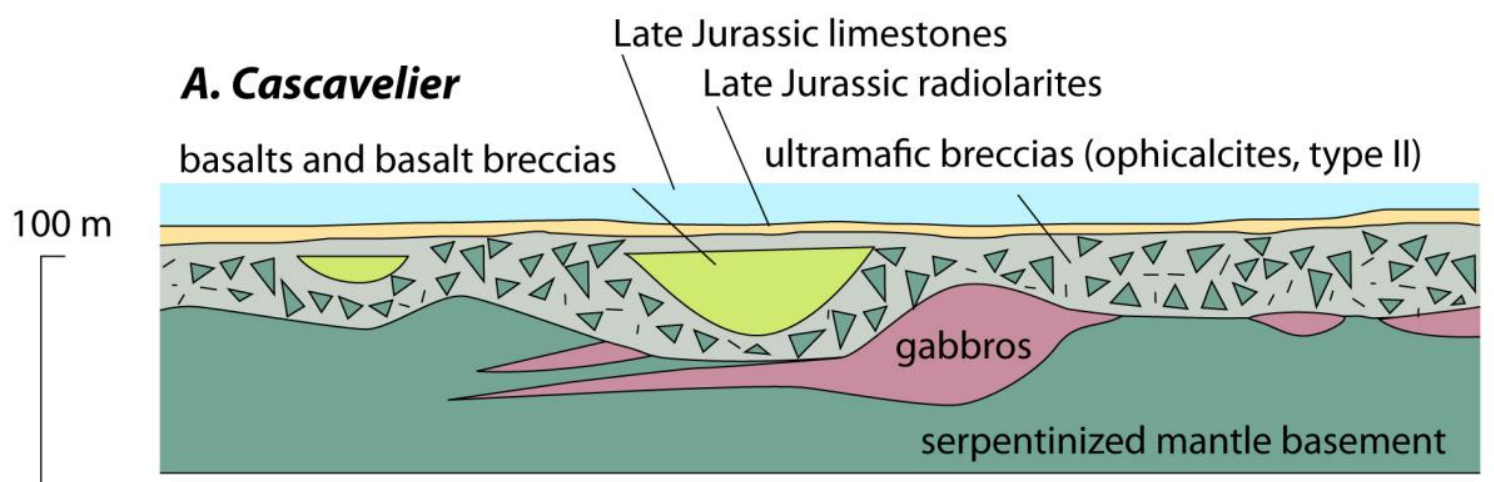

$500 \mathrm{~m}$

B. Roche Noire gabbro breccia ultramafic breccias (ophicalcites, type II)

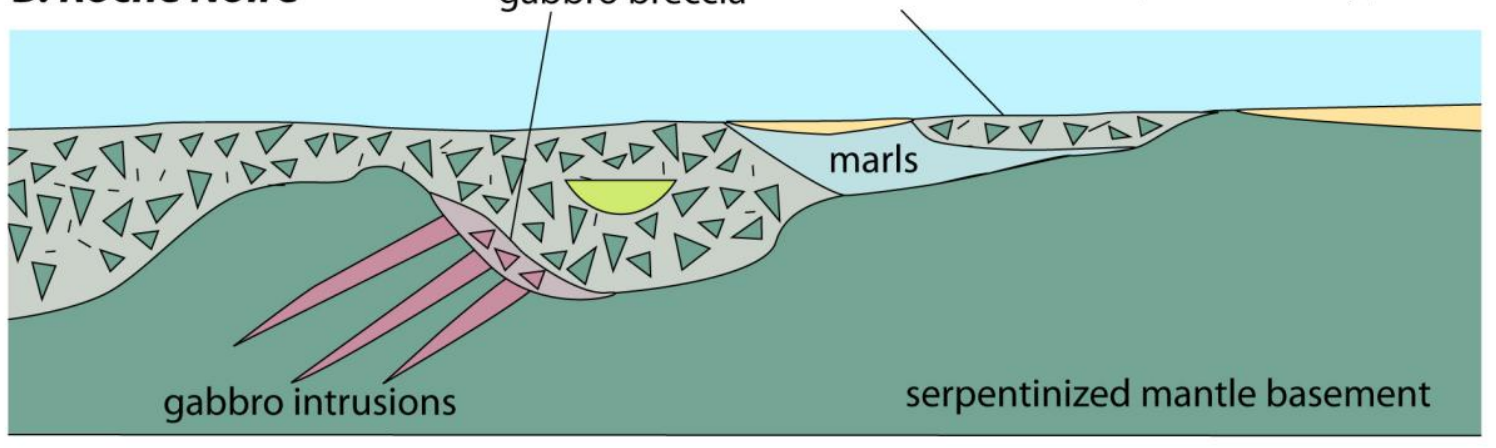

after Tricart and Lemoine, 1986

Lagabrielle et al. fig. 21 


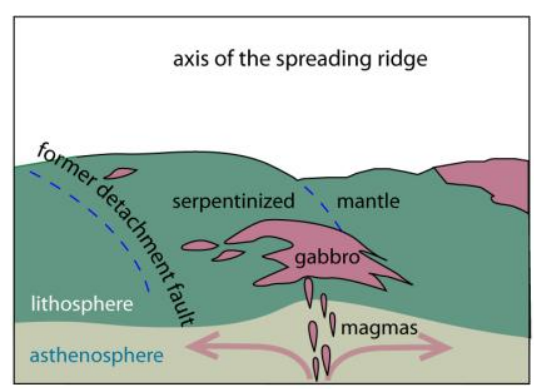

Plutonic stage : emplacement of gabbros within the mantle rocks at depth and initiation of detachment fault

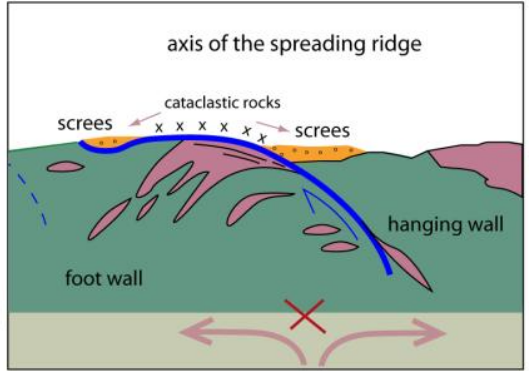

Tectonic stage : exhumation of the gabbros bodies and surrounding serpentinized mantle rocks.

Deposition of ophiolitic breccias in response to sedimentary reworking of cataclastic products

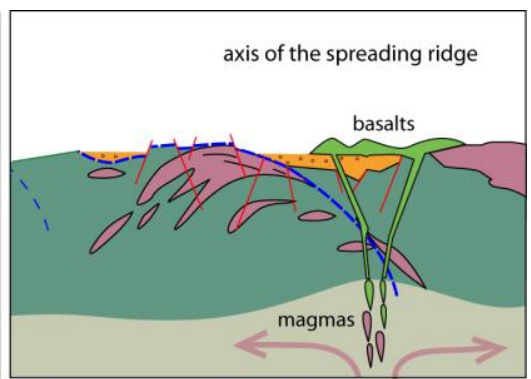

Volcanic stage : normal faulting of the axial region and eruption of scarce lava flows over a basement of exhumed serpentinized mantle rocks and gabbros together with abundant mafic-ultramafic breccias

\section{Lagabrielle et fig. 22}

